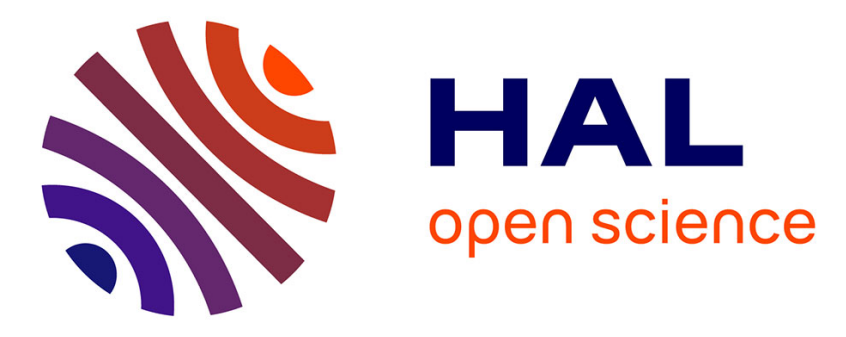

\title{
Long term monitoring of the chemical composition of precipitation and wet deposition fluxes over three Sahelian savannas
}

Dungall Laouali, Corinne Galy-Lacaux, Babakar Diop, Claire Delon, Didier Orange, Jean-Pierre Lacaux, Aristide Barthélémy Akpo, François Lavenu, Eric Gardrat, Pierre Castéra

\section{To cite this version:}

Dungall Laouali, Corinne Galy-Lacaux, Babakar Diop, Claire Delon, Didier Orange, et al.. Long term monitoring of the chemical composition of precipitation and wet deposition fluxes over three Sahelian savannas. Atmospheric environment, 2012, 50, pp.314-327. 10.1016/j.atmosenv.2011.12.004 . hal00766827

\section{HAL Id: hal-00766827 \\ https://hal.science/hal-00766827}

Submitted on 22 Sep 2021

HAL is a multi-disciplinary open access archive for the deposit and dissemination of scientific research documents, whether they are published or not. The documents may come from teaching and research institutions in France or abroad, or from public or private research centers.
L'archive ouverte pluridisciplinaire HAL, est destinée au dépôt et à la diffusion de documents scientifiques de niveau recherche, publiés ou non, émanant des établissements d'enseignement et de recherche français ou étrangers, des laboratoires publics ou privés. 


\title{
Long term monitoring of the chemical composition of precipitation and wet deposition fluxes over three Sahelian savannas
}

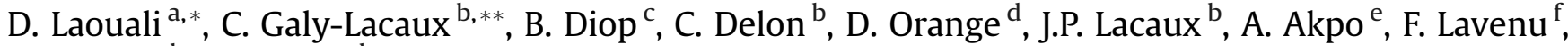 \\ E. Gardrat ${ }^{\text {b }}$, P. Castera ${ }^{\text {b }}$ \\ ${ }^{a}$ Université Abdou Moumouni, Faculté des Sciences, BP 10662, Niamey, Niger \\ ${ }^{\mathrm{b}}$ Laboratoire d'Aérologie, 14 Av. Edouard Belin, 31400 Toulouse, France \\ ${ }^{\mathrm{c}}$ Université de Bamako, Mali \\ d IRD-UMR211 BIOEMCO, 32 av. H. Varagnat, 93143 Bondy cedex, France \\ e Université Abomey Calavi, Cotonou, Benin \\ ${ }^{\mathrm{f}}$ CESBIO, Toulouse, France
}

The purpose of this study is to analyze a long term database of the chemical composition of precipitation at three African dry savanna sites in the Sahel. The precipitation samples were collected during the monsoon season at Agoufou $\left(1^{\circ} 20^{\prime} \mathrm{N}, 01^{\circ} 29^{\prime} \mathrm{W}\right.$, Mali) from 2004 to 2006 , Banizoumbou $\left(13^{\circ} 31^{\prime} \mathrm{N}\right.$, $02^{\circ} 38^{\prime} \mathrm{E}$, Niger) from 1994 to 2009 and Katibougou $\left(12^{\circ} 56^{\prime} \mathrm{N}, 07^{\circ} 32^{\prime} \mathrm{W}\right.$, Mali) from 1997 to 2008 . pH and major inorganic and organic ions in precipitation were analyzed by ionic chromatography. A characterization of mean precipitation chemistry with the associated wet deposition fluxes for each species is presented. The first important result is that interannual variability of all volume-weighted mean (VWM) concentrations is low, ranging between $\pm 5 \%$ and $\pm 25 \%$. Acidity in dry savannas is low and indicates the strong alkaline nature of the precipitation. The average annual pH at Agoufou is 6.28, 5.75 at Banizoumbou and 5.54 at Katibougou. This result is correlated with the important terrigenous contribution measured in the chemical content of precipitation, implying acidity neutralization by mineral species such as $\mathrm{Ca}^{2+}$ and $\mathrm{NH}_{4}^{+} \cdot \mathrm{Mg}^{2+}$ and $\mathrm{K}^{+}$are found to play a minor role in neutralization. Enrichment factor calculations for $\mathrm{Ca}^{2+}, \mathrm{SO}_{4}^{-}, \mathrm{K}^{+}$and $\mathrm{Mg}^{2+}$ with respect to the sea reference reveal a significant influence of Saharan and Sahelian crustal sources. VWM concentrations of these species dominate the composition of measured precipitation. An estimation of the potential particulate and gas contribution to the total precipitation composition is given for each site: At Agoufou, the mean relative contribution in rainwater is $80 \%$ for particles and $20 \%$ for gases, while at the Banizoumbou and Katibougou sites, results indicate $70 \%$ for particles and $30 \%$ for gases. The high particulate phase contribution to precipitation emphasizes the importance of multiphase processes between gases and particles in the atmospheric chemistry typical of African semi-arid savanna ecosystems. The second highest contribution is nitrogenous, with high VWM concentrations of $\mathrm{NO}_{3}^{-}$and $\mathrm{NH}_{4}^{+}$measured at the three sites. Monthly evolution of $\mathrm{NO}_{3}^{-}$and $\mathrm{NH}_{4}^{+}$concentrations are studied in relation to gaseous emission sources in the Sahelian region, i.e. biogenic soil emission and ammonia sources from animals. The calculated wet nitrogen deposition flux presents a regular increase throughout the wet season at the three sites. Results suggest total mean nitrogen deposition fluxes of $1.80 \mathrm{~kg} \mathrm{~N} \mathrm{ha}^{-1} \mathrm{yr}^{-1}$ at Agoufou, $2.10 \mathrm{~kg} \mathrm{~N} \mathrm{ha}^{-1} \mathrm{yr}^{-1}$ at Banizoumbou, and $3.30 \mathrm{~kg} \mathrm{~N} \mathrm{ha}^{-1} \mathrm{yr}^{-1}$ at Katibougou. The marine contribution is lower, $23 \%$ at Agoufou, $17 \%$ at Banizoumbou and $13 \%$ at Katibougou. The last contribution concerns organic acidity, which ranges from $5 \%$ at Agoufou, $10 \%$ at Banizoumbou to $14 \%$ at Katibougou. Terrigenous and marine contributions present a negative gradient, whereas nitrogenous and organic contributions a positive gradient along the Sahelian transect defined by Agoufou-Banizoumbou-Katibougou.

\footnotetext{
* Corresponding author.

** Corresponding author. Tel.: +33561332706.

E-mail addresses: laoualid@yahoo.fr (D. Laouali), lacc@aero.obs-mip.fr (C. Galy-Lacaux).
}

\section{Introduction}

In arid and semi-arid regions desertification is a land degradation problem of major importance resulting from various factors including climatic variations and human activities i.e. soil erosion 
caused by wind and/or water, deterioration of soil properties and natural vegetation. High demographic growth and rapid development of economic activities has resulted in an agricultural intensification process to increase food production complicating the situation of desertification. The arid and semi-arid regions, because of their particular climate, where wind erosion frequently exceeds water erosion, are the principal sources of atmospheric dust transported over great distances from eroded soils (Orange et al., 1993; Gomes et al., 2003). Soil erosion is a major global environmental and agricultural problem, which has intensified in recent years. In the tropics, the atmosphere has a high dust load throughout the year as a result of the common occurrence of "dust devils" (Saxena et al., 1996). Dust devils are local convective circulations that occur particularly in arid and semi-arid environments. In recent years, multidisciplinary research has received considerable attention, mainly within arid and semi-arid regions where ecosystems are characterized by low, discrete rainfall, high temperatures, periodic droughts and little vegetation cover (Estell et al., 2006).

Various sources from natural and anthropogenic activities influence the chemical composition of precipitation. Chemical species in rainfall may differ from those originally emitted e.g. emission of alkaline (dust particles and gaseous $\mathrm{NH}_{3}$ ) can significantly influence precipitation acidity by neutralizing a certain fraction of the acids (Placet and Streets, 1987; Khemani et al., 1993). The mineral acidity in precipitation is mainly related to the acids $\mathrm{HNO}_{3}$ and $\mathrm{H}_{2} \mathrm{SO}_{4}$ formed from $\mathrm{NO}_{\mathrm{x}}$ and $\mathrm{SO}_{2}$ gaseous precursors.

In Africa, the IDAF (IGAC/DEBITS/AFRICA) program started in 1994. The IDAF network is the French contribution to the international IGAC (International Global Atmospheric Chemistry)/DEBITS (Deposition of Biogeochemically Important Trace Species) program. The IDAF program is associated with the African Monsoon Mutidisciplinary Analysis/Long Observing Period (AMMA/LOP, Lebel et al., 2010) over West/Central Africa and with the South Africa Climate Change Air Pollution-PICS (SACCLAP) project in southern Africa. The main objectives of IDAF are to measure wet and dry deposition fluxes and identify the relative contribution of natural and anthropogenic sources. The IDAF activity is based on high quality measurements of atmospheric chemistry (rainwater, aerosol and gaseous chemical composition) on the multi-year scale. 10 measurement sites exist covering three types of African ecosystems: dry savanna (Niger, Mali and South Africa), wet savanna (Ivory Coast and Benin) and equatorial forest (Cameroon and Congo) (Fig. 1). Data from the measuring sites at Agoufou (Mali), Banizoumbou (Niger) and Katibougou (Mali), which represent the Sahelian dry savanna sites, are analyzed here.

Wet and dry deposition play an essential role in controlling the concentration of biogeochemical elements in the atmosphere. The chemical content of precipitation integrates numerous physical and chemical mechanisms. Therefore, the study of precipitation composition and associated wet deposition is linked to the temporal and spatial evolution of atmospheric chemistry. Moreover, the identification of chemical and physical characteristics of rainwater helps to evaluate the influence of different sources and enhances the understanding of the local and regional dispersion of gases and particles as well as their potential impacts on ecosystems. Incorporation of $\mathrm{S}$ and $\mathrm{N}$ oxides in wet deposition is particularly important as they are precursors of major acids $\mathrm{H}_{2} \mathrm{SO}_{4}$ and $\mathrm{HNO}_{3}$ (Ro et al., 1988; Minoura and Iwasaka, 1996; Voldner et al., 1986; Dikaiakos et al., 1990).

Precipitation influences the removal of particulate matter and gaseous pollutants in the atmosphere. The physico-chemical characterization of precipitation continues to be investigated due to the increased atmospheric input of substances and their effects upon terrestrial ecosystems, surface waters, vegetation and materials (Bravo et al., 2000).

Recent studies of precipitation chemistry in African ecosystems have been published as part of the IDAF network, e.g. Galy-Lacaux and Modi (1998); Galy-Lacaux et al., 2001; Al-ourabi and Lacaux (2002); Lacaux et al. (1993, 2003); Yoboué et al. (2005); SighaNkamdjou et al. (2003); Mphepya at al. (2004, 2005); Galy-Lacaux et al. (2009).

The present work complements these studies on precipitation content at other African sites. The main objectives of this study are to:

- provide the main precipitation chemistry characteristics and a quantification of wet deposition fluxes representative of dry African savanna ecosystems;

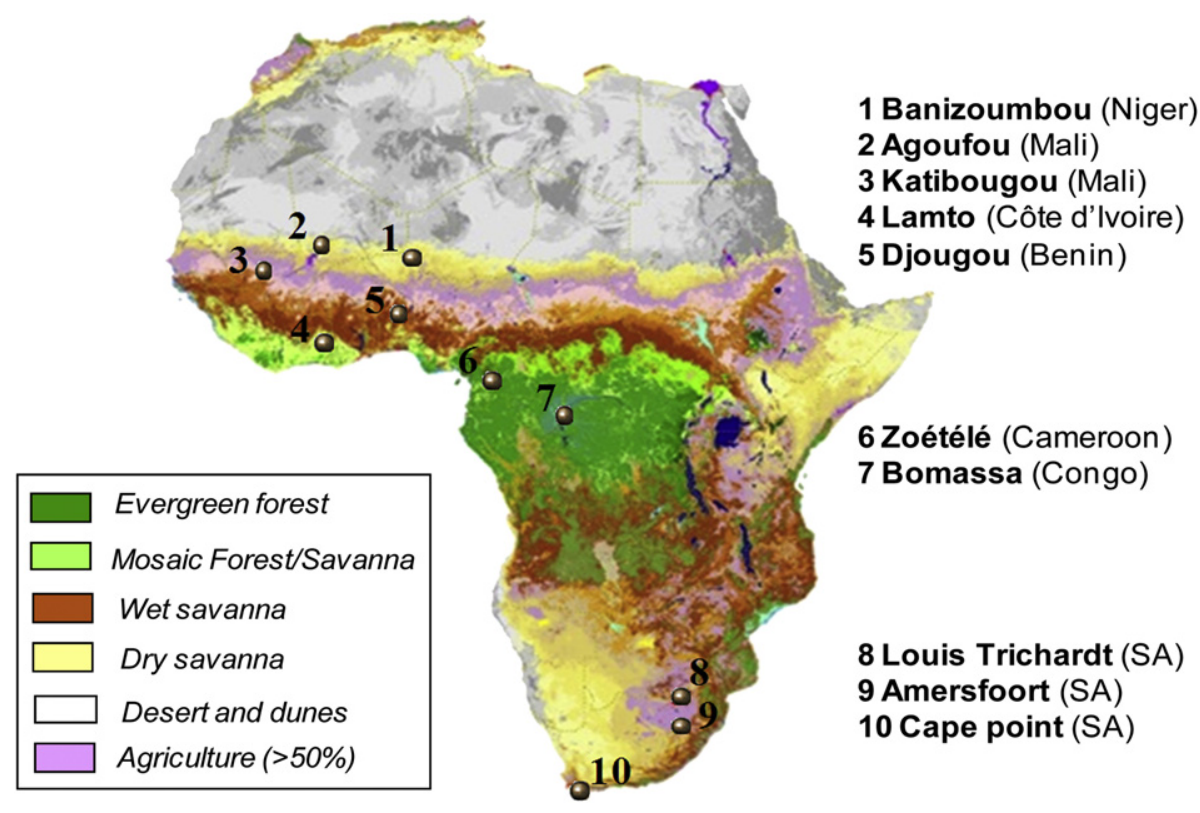

Fig. 1. Vegetation and location map of the 10 measurement stations of the IDAF network. 
- study the temporal and spatial trends of the chemical composition of rainwater and associated wet deposition fluxes during the monsoon season;

- compare the results between the three dry savanna sites as well as with the other IDAF sites representative of semi-arid savanna in South Africa, wet savanna in Lamto (Ivory Coast) and equatorial forest in Zoetele (Cameroon);

- investigate the variability of the main atmospheric sources of nitrogenous species in the gas phase that influence ammonium and nitrate content in precipitation.

\section{Materials and methods}

\subsection{Sampling sites}

Fig. 1 presents the vegetation map and location of the 10 IDAF measurement stations. Sites are displayed on the land cover map of Africa from Mayaux et al. (2004). We focus on the three Sahelian sites, Katibougou, Agoufou and Banizoumbou, situated in Mali and Niger. Rainfall samples were collected at Agoufou (Mali) from 2004 to 2006, at Banizoumbou (Niger) from 1994 to 2009 and at Katibougou (Mali) from 1997 to 2008. Galy-Lacaux et al. (2009) have published a long term synthesis of precipitation chemistry at Banizoumbou (Niger) using data from 1994 to 2005. The three sites used here are representative of rural and agro-pastoral sites in Western African dry savannas ecosystems. Measurements of rainwater, aerosol chemical composition and surface gaseous concentrations were made at all three sites (Adon et al., 2010). The Agoufou site was incorporated into the IDAF network in the framework of the AMMA (African Monsoon Multidisciplinary Analysis) program in 2004. Activity at this site stopped in 2006 in terms of rainfall observations but measurements of gaseous concentrations continue.

Rainfall in the Sahel is governed by the West African monsoon system. The Western African climate is largely determined by the position of the Inter-Tropical Convergence Zone (ITCZ), which separates the hot and dry continental air coming from the Sahara desert (Harmattan) from the cooler, humid maritime air masses (Monsoon) originating from the equatorial Atlantic Ocean. In the Sahel, $80 \%$ of the total rainfall is associated with mesoscale convective systems during the summer monsoon in June and July (Mohr et al., 2009). Mesoscale convective systems (MCS) are also responsible for the major fraction of annual, local wind erosion and hence for most of the Sahelian dust emissions (Janicot et al., 2008). The three stations investigated have a semi-arid climate, with a dry season from October to May and a wet season from June to September. The sites are located along a latitudinal gradient and are briefly described in Table 1 . Agoufou is situated towards the northern limit of the area reached by the West African monsoon and is part of the Malian Gourma mesocale site of the AMMA CATCH program (Couplage de L'Atmosphère Tropicale et du Cycle Hydrologique) (Mougin et al., 2009). Mean annual rainfall over the three-year study period was $321 \mathrm{~mm}$ (Table 1). Banizoumbou is situated about $60 \mathrm{~km}$ east of Niamey in a rural and agro-pastoral area of the Sahelian region of Niger. Annual average rainfall over the 15-year study period was $509 \mathrm{~mm}$ (Table 1 ). More detailed information for these two sites is available in Galy-Lacaux and Modi (1998) and Galy-Lacaux et al. (2009). Katibougou is located in the Koulikoro region, at the IPR center (Institut Polytechnique Rural) approximately $60 \mathrm{~km}$ northeast of Bamako. This site represents a rural site in the Sudano-Sahelian zone with some extended agricultural practices nearby. Annual precipitation varied from a minimum of $585 \mathrm{~mm}$ in 2000 to a maximum $1039 \mathrm{~mm}$ in 1999. Mean annual rainfall for the 1997 to 2008 period was $804 \mathrm{~mm}$ (Table 1).

\subsection{Rain collection}

An automatic precipitation collector specially designed for the IDAF network was located in the three IDAF sites (Galy-Lacaux et al., 2009). The automatic instrument is designed to collect only wet deposition. It collects precipitation with a high degree of cleanliness in a single-use polyethylene bag, avoiding aerosol deposit before the onset of rain. A precipitation detector automatically controls the aperture of the cover, which hermetically closes the polyethylene bag. The surface of rain collection is $225 \mathrm{~cm}^{2}$. After each precipitation event, $50 \mathrm{~cm}^{3}$ of the collected precipitation is sampled in $50 \mathrm{ml}$ Greiner tubes. The preservation of the rainwater samples is an important problem because microbial degradation can modify the chemical composition of rainwater. For this study all samples were stored in a deep freeze environment from collection to analysis.

A total of 61 precipitation events were collected at Agoufou, 358 at Banizoumbou and 510 at Katibougou, representing total collected rainfall amounts of 764, 6880 and $8337 \mathrm{~mm}$, respectively. Table 1 presents the calculated mean efficiency of collection (EC) for each site. These values indicate a good representativity of the dataset in accordance with the precipitation completeness quality criteria given by the Global Atmospheric Watch (GAW) Program of the World Meteorological Organization (WMO, 2004).

\subsection{Analytical procedure and data quality control of rain samples}

Precipitation-dissolved content was determined at the Laboratory of Aerology (LA), Toulouse, France. Inorganic and organic ions were determined by ion chromatography (IC). All details of analytical procedures are described by Galy-Lacaux et al. (2009). The quality of measurements depends not only on the samples but also on the analysis and the standardized and accredited procedures. Since 1996, the Laboratory of Aerology has participated in the quality control inter-comparison program organized twice a year by the WMO GAW. Fig. 2 summarizes the results from last five tests (2005-2009) from the laboratory of Aerology WMO intercomparison. According to the results of the quality assurance program, analytical precision is estimated to be $5 \%$ or better for all ions, well within the uncertainties of all measured values presented here.

$\mathrm{pH}$ is measured with an ATI Orion 350 instrument with a combined electrode (ATI Orion model 9252) filled with $\mathrm{KCl}(4 \mathrm{M})$ and saturated with $\mathrm{AgCl}$. Two standard solutions (WTW) at $\mathrm{pH} 4.01$ and 7.00 are used for its calibration. $\mathrm{H}^{+}$ion concentrations are

Table 1

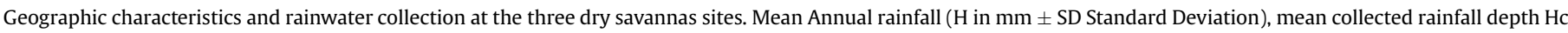
in $\mathrm{mm}$ and mean Efficiency Collection (EC) in \%.

\begin{tabular}{|c|c|c|c|c|c|c|c|}
\hline Station & Country & Latitude & Longitude & Elevation $\mathrm{m}^{-1}$ & $\mathrm{H}(\mathrm{mm}) \pm \mathrm{SD}$ & $\mathrm{Hc}(\mathrm{mm})$ & $\mathrm{EC}(\%)$ \\
\hline Agoufou (2004-2006) & Mali & $15^{\circ} 20^{\prime} \mathrm{N}$ & $01^{\circ} 29^{\prime} \mathrm{W}$ & 300 & $321 \pm 19$ & 254 & 78 \\
\hline Banizoumbou (1994-2009) & Niger & $13^{\circ} 31^{\prime} \mathrm{N}$ & $02^{\circ} 38^{\prime} \mathrm{E}$ & 220 & $509 \pm 34$ & 459 & 89 \\
\hline Katibougou (1997-2008) & Mali & $12^{\circ} 56^{\prime} \mathrm{N}$ & $07^{\circ} 32^{\prime} \mathrm{W}$ & 290 & $804 \pm 31$ & 695 & 89 \\
\hline
\end{tabular}




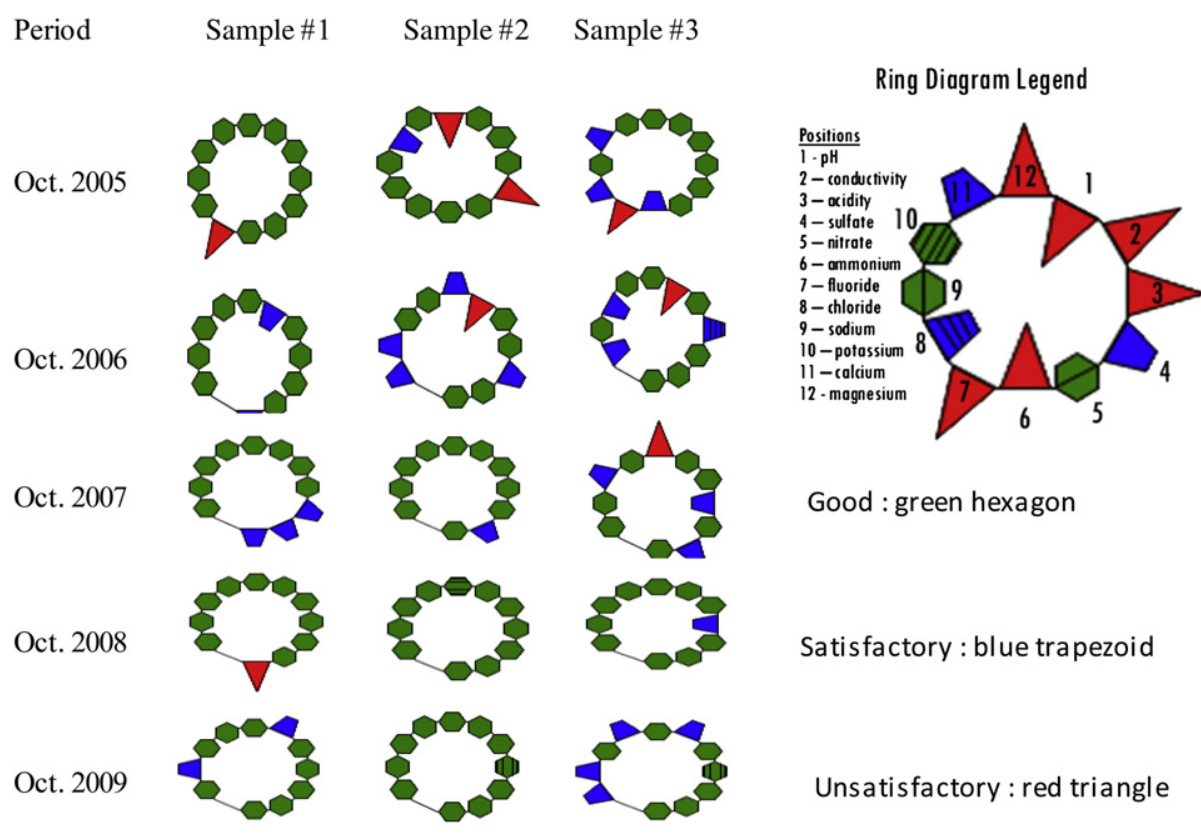

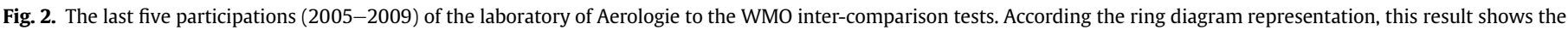
analysis of 3 blind samples analyzed by the laboratory of Aerologie and compared to WMO referenced values.

calculated from the $\mathrm{pH}$. Precision is $0.01 \mathrm{pH}$ units. To improve the quality of the IDAF dataset further, the WMO quality criteria based on the ionic balance were applied to all the IDAF precipitation samples (WMO, 2004). A calculation of the ion difference (ID) for each sample is performed to consider the ionic balance with the following equation:

Ion Difference $(\%)=100 \times([\mathrm{CE}-\mathrm{AE}] /[\mathrm{CE}+\mathrm{AE}])$

where $A E$ is the anion sum in $\mu e q \mathrm{l}^{-1}$ and $C E$ is the cation sum in $\mu$ eq $\mathrm{l}^{-1}$. Acceptable ID according to the total sample ionic charge is given by the WMO GAW manual report, 2004. 91, 94 and 92\% of all samples at Agoufou, Banizoumbou and Katibougou, respectively, were within the WMO acceptance range. Only these samples have been used in the calculations presented in this paper.

\subsection{Calculation of annual volume-weighted mean concentration and wet deposition}

The annual volume-weighted mean concentration (VWM) of each ion was calculated using the following relationship:

$\operatorname{VMW}\left(\right.$ eеq $\left.1^{-1}\right)=\sum_{i=1}^{N} c_{i} p_{i} / \sum_{i=1}^{N} p_{i}$

where $C_{i}$ is the ion concentration for each element in $\mu$ eq $\mathrm{l}^{-1}, P_{i}$ the precipitation amount for each rainfall event in $\mathrm{mm}$, and $\mathrm{N}$ the total number of samples. To calculate the mean VWM concentration of each ion over the period 2004-2006 at Agoufou, 1994-2009 at Banizoumbou and 1997-2008 at Katibougou, $\mathrm{N}$ is considered equal to $61,358,510$, respectively.

The annual wet deposition (WD) expressed in $\mathrm{mmol} \mathrm{m}^{-2} \mathrm{yr}^{-1}$ is calculated by multiplying the VWM concentrations by the annual average rainfall amount. From the VWM concentrations of the components in $\mathrm{mg} \mathrm{L}^{-1}$, o the wet deposition in $\mathrm{kg} \mathrm{ha}^{-1} \mathrm{yr}^{-1}$ can be obtained. The Efficiency Collection (EC\%) that represents the completeness of precipitation depth associated with valid chemical composition analysis is between 80 and $90 \%$ for all sites. The analytical precision is estimated to be $5 \%$ or better for all ions.
A principal component analysis (PCA) was applied to all the rainwater measurements. The correlation coefficients between the different chemical parameters are examined in order to determine the potential sources that influence rainwater composition. High correlation indicates that chemical compounds may have the same origin and/or are affected by advection of the same air masses.

To estimate the contribution of the sea salt component to the measured precipitation composition, excess concentrations of sulphate, chloride, potassium, calcium and magnesium with respect to sea salt are calculated using $\mathrm{Na}^{+}$reference (Keene et al., 1986). The sea salt fraction of any particular species, $X$, is given by:

$\mathrm{ssF}_{\mathrm{X}}=\left[\mathrm{Na}_{\text {rain }}^{2+}\right]\left[\mathrm{X} / \mathrm{Na}^{2+}\right]_{\text {seawater, }}$

Similarly, the non-sea salt fraction of $\mathrm{X}$ can also be given by:

$\mathrm{nssF}_{\mathrm{X}}=\left[\mathrm{X}_{\text {rain }}\right]-\left[\left\{\mathrm{Na}_{\text {rain }}^{2+}\right\} *\left\{\mathrm{X} / \mathrm{Na}^{2+}\right\}_{\text {seawater }}\right]$

where $X_{\text {rain }}$ is the concentration of species $X$ in rainwater. The corresponding enrichment factor (EF) of different components with respect to $\mathrm{Na}^{+}$are calculated using equation (5):

$(\mathrm{EF})_{\mathrm{X}}=\left(\mathrm{X} / \mathrm{Na}^{+}\right)_{\text {rain }} /\left(\mathrm{X} / \mathrm{Na}^{+}\right)_{\text {seawater }}$

where $(E F)_{X}$ is the enrichment factor of species $X, \mathrm{Na}^{+}$is a reference element for the sea, $\left(X / \mathrm{Na}^{+}\right)$rain is the ratio of the amount of species $\mathrm{X}$ to that of species $\mathrm{Na}^{+}$in the rain, and $\left(\mathrm{X} / \mathrm{Na}^{+}\right)$ seawater is the ratio of species $\mathrm{X}$ to species $\mathrm{Na}^{+}$in the seawater (Chao and Wong, 2002; Quiterio et al., 2004).

\section{Results and discussion}

In this section we study the mean monthly and annual chemical composition of precipitation, as well as the wet deposition fluxes estimated at the three measurement sites. Table 2 presents the calculated annual VWM concentrations and the annual mean WD for all data. The entire database is used to study the temporal and spatial trends of the chemical composition of rainwater and 
Table 2

Volume-Weighted Mean concentration VWM ( $\mu$ eq $\left.\mathrm{l}^{-1}\right)$ and Wet Deposition WD $\left(\mathrm{kg} \mathrm{ha}^{-1} \mathrm{yr}^{-1}\right)$ measured at the three Sahelian savannas.

\begin{tabular}{|c|c|c|c|c|c|c|}
\hline \multirow[t]{2}{*}{ Species } & \multicolumn{2}{|c|}{ Agoufou (2004-2006) } & \multicolumn{2}{|c|}{ Banizoumbou (1994-2009) } & \multicolumn{2}{|c|}{ Katibougou (1997-2008) } \\
\hline & VWM $\left(\mu e q \mathrm{I}^{-1}\right)$ & WD $\left(\mathrm{kg} \mathrm{ha}^{-1} \mathrm{yr}^{-1}\right)$ & VWM ( $\mu$ eq $\mathrm{l}^{-1}$ ) & WD $\left(\mathrm{kg} \mathrm{ha}^{-1} \mathrm{yr}^{-1}\right)$ & $\operatorname{VWM}\left(\mu \mathrm{eq} \mathrm{l^{-1 }}\right)$ & WD $\left(\mathrm{kg} \mathrm{ha}^{-1} \mathrm{yr}^{-1}\right)$ \\
\hline $\mathrm{H}^{+}$ & $0.5( \pm 0.2)$ & $0.002( \pm 0.001)$ & $1.8( \pm 0.5)$ & $0.009( \pm 0.003)$ & $3.0( \pm 1.0)$ & $0.024( \pm 0.007)$ \\
\hline $\mathrm{pH}$ & $6.28( \pm 0.15)$ & - & $5.75( \pm 0.14)$ & - & $5.54( \pm 0.14)$ & - \\
\hline $\mathrm{Na}^{+}$ & $18.8( \pm 1.2)$ & $1.36( \pm 0.32)$ & $9.9( \pm 2.9)$ & $1.17( \pm 0.47)$ & $6.3( \pm 1.8)$ & $1.16( \pm 0.41)$ \\
\hline $\mathrm{NH}_{4}^{+\mathrm{a}}$ & $25.2( \pm 2.0)$ & $1.12( \pm 0.26)$ & $17.9( \pm 3.5)$ & $1.29( \pm 0.37)$ & $19.1( \pm 3.7)$ & $2.13( \pm 0.50)$ \\
\hline $\mathrm{K}^{+}$ & $12.4( \pm 0.7)$ & $1.55( \pm 0.39)$ & $8.1( \pm 2.9)$ & $1.66( \pm 0.77)$ & $3.7( \pm 1.0)$ & $0.12( \pm 0.04)$ \\
\hline $\mathrm{Ca}^{2+}$ & $32.3( \pm 1.5)$ & $2.09( \pm 0.56)$ & $27.0( \pm 4.8)$ & $2.75( \pm 0.62)$ & $22.9( \pm 2.7)$ & $3.65( \pm 0.60)$ \\
\hline $\mathrm{Mg}^{2+}$ & $16.5( \pm 2.9)$ & $0.67( \pm 0.23)$ & $7.3( \pm 2.0)$ & $0.46( \pm 0.17)$ & $4.5( \pm 1.3)$ & $0.43( \pm 0.12)$ \\
\hline $\mathrm{NO}_{3}^{-\mathrm{a}}$ & $14.6( \pm 0.8)$ & $0.66( \pm 0.19)$ & $10.8( \pm 2.5)$ & $0.77( \pm 0.20)$ & $10.4( \pm 2.0)$ & $1.16( \pm 0.28)$ \\
\hline $\mathrm{Cl}^{-}$ & $20.2( \pm 0.1)$ & $2.30( \pm 0.60)$ & $9.9( \pm 3.0)$ & $1.82( \pm 0.81)$ & $6.5( \pm 1.8)$ & $1.86( \pm 0.66)$ \\
\hline $\mathrm{SO}_{4}^{2-\mathrm{b}}$ & $14.3( \pm 3.3)$ & $0.70( \pm 0.13)$ & $9.7( \pm 1.6)$ & $0.80( \pm 0.23)$ & $7.3( \pm 1.1)$ & $0.94( \pm 0.20)$ \\
\hline $\mathrm{tCarb}^{\mathrm{c}}$ & $39.6( \pm 1.7)$ & $7.77( \pm 2.10)$ & $28.5( \pm 6.4)$ & $8.82( \pm 2.14)$ & $19.1( \pm 5.8)$ & $9.35( \pm 3.21)$ \\
\hline $\mathrm{HCOO}^{-}$ & $4.5( \pm 1.1)$ & $0.67( \pm 0.26)$ & $6.6( \pm 2.2)$ & $0.82( \pm 0.46)$ & $10.3( \pm 3.1)$ & $3.71( \pm 1.08)$ \\
\hline $\mathrm{CH}_{3} \mathrm{COO}^{-}$ & $3.9( \pm 1.1)$ & $0.74( \pm 0.28)$ & $6.6( \pm 2.2)$ & $0.68( \pm 0.36)$ & $5.2( \pm 1.7)$ & $2.44( \pm 0.74)$ \\
\hline $\mathrm{C}_{2} \mathrm{H}_{5} \mathrm{COO}^{-}$ & $0.2( \pm 0.1)$ & $0.04( \pm 0.01)$ & $0.3( \pm 0.3)$ & $0.05( \pm 0.05)$ & $0.1( \pm 0.1)$ & $0.09( \pm 0.07)$ \\
\hline $\mathrm{C}_{2} \mathrm{O}_{4}^{2-}$ & $2.2( \pm 0.8)$ & $0.15( \pm 0.06)$ & $1.8( \pm 0.6)$ & $0.05( \pm 0.02)$ & $1.8( \pm 0.9)$ & $0.35( \pm 0.12)$ \\
\hline
\end{tabular}

a $\mathrm{NH}_{4}^{+}$and $\mathrm{NO}_{3}^{-}$in $\mathrm{kg} \mathrm{N} \mathrm{ha}^{-1} \mathrm{yr}^{-1}$.

b $\mathrm{SO}_{4}^{2-}$ in $\mathrm{kg} \mathrm{S}^{-1} \mathrm{yr}^{-1}$.

c tcarb: is total carbonates.

associated wet deposition during the measurement period. Special focus is placed on the investigation of the concentration and wet deposition of nitrogenous compounds. We investigate the variability of the main gas phase atmospheric sources that influence ammonium and nitrate precipitation content. We also quantify and study the seasonal evolution of nitrogen wet deposition fluxes, which are key in terms of natural input to soils and vegetation in semi-arid regions in developing nations.

\subsection{Chemical composition of precipitation and wet deposition fluxes}

Table 2 presents the mean annual VWM concentrations and wet deposition fluxes as well as the associated standard deviations for all species measured at the three IDAF sites. All standard deviations are low, never exceeding $\pm 6.4 \%$. These values are therefore representative of a mean characterization of the rainfall chemical content and the associated fluxes for the reported time periods.

Correlation coefficients between the different ionic species using the Spearman method (with a 1\% confidence level) are calculated for all individual events.

\subsubsection{Marine contribution}

According to the method described in Section 2.4, marine and non-marine contributions of the different ionic species in precipitation and the corresponding Enrichment Factors (EF) were estimated. Table 3 shows the ratio of $\mathrm{Ca}^{2+}, \mathrm{SO}_{4}^{2+}, \mathrm{Mg}^{2+}$ and $\mathrm{K}^{+}$with respect to $\mathrm{Na}^{+}$in rainwater and seawater, as well as their enrichment factors (EF). $\mathrm{Na}^{+}$and $\mathrm{Cl}^{-}$ions are highly correlated $(r=0.78$, 0.76 and 0.92, at Agoufou, Banizoumbou and Katibougou, respectively). These mean annual ratios of these two ions are 1.074, 1.000 and 1.032, at the three sites respectively; values which are close to the sea-water ratio of 1.167 (Keene et al., 1986), and which correspond to the same EF value close between 0.9 and 1 . The ratios of
$\mathrm{SO}_{4}^{2-} / \mathrm{Na}^{+}, \mathrm{K}^{+} / \mathrm{Na}^{+}, \mathrm{Ca}^{2+} / \mathrm{Na}^{+}$and $\mathrm{Mg}^{2+} / \mathrm{Na}^{+}$in rainwater at the three sites were found to be higher than the seawater ratios. In addition to the marine contribution of these species, high ratios of $\mathrm{SO}_{4}^{2-}, \mathrm{K}^{+}, \mathrm{Ca}^{2+}$ and $\mathrm{Mg}^{2+}$ suggest a non-marine origin for these species. Similar results were found by Khemani et al. (1993) and Kulshrestha et al. (2003, 2005, 2009) for Indian sites. These elevated values indicate a contribution from crustal sources. The values of the sea salt fraction (ssF) and non-sea salt fraction (nssF) support this observation (Table 4). Crustal sources contribute between 84 and $90 \% \mathrm{SO}_{4}^{2-}, 96-96 \% \mathrm{~K}^{+}, 98-99 \% \mathrm{Ca}^{2+}$ and $68-74 \%$ $\mathrm{Mg}^{2+}$ at the three sites.

Fig. 4 gives an example of a marine episode as it occurs generally during the wet season in the Sahel. Back trajectory analyzes, were calculated using the NOAA HYSPLIT MODEL (Draxler and Rolph, 2003), at the three dry savanna sites for the monsoon season at a constant altitude of $500 \mathrm{~m}$. Results clearly indicate that the monsoonal air masses coming from the Guinean Gulf are rich in sea salt aerosols and influence the three Sahelian sites, despite their distance from the sea. The marine contributions for $\mathrm{Mg}^{2+}, \mathrm{SO}_{4}^{2-}, \mathrm{K}^{+}$, $\mathrm{Ca}^{2+}$ are estimated to be around $26 \%, 16 \%, 3 \%$ and $2 \%$, respectively, at Agoufou, $31 \%, 12 \%, 3 \%$ and $1 \%$ at Banizoumbou and $32 \%, 10 \%, 4 \%$ and $1 \%$ at Katibougou. Contribution of the $\mathrm{Mg}^{2+}$ content in rain is estimated for the three sites and ranges from 26 to $32 \%$ and from 68 to $74 \%$ for marine and terrigenous sources, respectively. In Africa, convective rainfall includes marine elements from the boundary layer and terrigenous elements from atmospheric levels above the boundary layer which are affected by continental air masses. We clearly retrieve these two chemical signatures during the monsoon season along the Sahelian transect investigated.

\subsubsection{Terrigenous contribution}

Measured total carbonates and calcium ions are the most abundant species with concentrations of 32.3, 27.0 and $22.9 \mu$ eq $1^{-1}$, at Agoufou, Banizoumbou and Katibougou, respectively. $\mathrm{Ca}^{2+}$ was

Table 3

Comparison of seawater ratios with rainwater components at the three IDAF savanna sites.

\begin{tabular}{|c|c|c|c|c|c|c|}
\hline Sea water rain & & 1.16 & 0.121 & 0.022 & 0.044 & 0.227 \\
\hline \multirow[t]{3}{*}{ Ratios in rain } & Agoufou (2004-2006); this work. & 0.681 & 0.404 & 0.435 & 1.276 & 0.430 \\
\hline & Banizoumbou (2006-2007); this work. & 1.000 & 0.815 & 1.105 & 2.277 & 0.805 \\
\hline & Katibougou (1997-2008); this work. & 1.035 & 1.281 & 0.632 & 4.719 & 0.789 \\
\hline \multirow[t]{3}{*}{ Enrichment factor } & Agoufou (2004-2006); this work. & 0.6 & 3.3 & 19.8 & 29.0 & 1.9 \\
\hline & Banizoumbou (2006-2007); this work. & 0.9 & 6.7 & 50.2 & 51.8 & 3.5 \\
\hline & Katibougou (1997-2008); this work. & 0.9 & 10.2 & 27.6 & 78.6 & 3.2 \\
\hline
\end{tabular}


Table 4

Non-sea salt (nss) and sea salt (ss) of rainwater components at the three dry savannas.

\begin{tabular}{lccc}
\hline Ion & $\begin{array}{l}\text { Agoufou } \\
\left(\mu \mathrm{eq} \mathrm{I}^{-1}\right)\end{array}$ & $\begin{array}{l}\text { Banizoumbou } \\
\left(\mu \mathrm{eq} \mathrm{I}^{-1}\right)\end{array}$ & $\begin{array}{l}\text { Katibougou } \\
\left(\mu \mathrm{eq} \mathrm{I}^{-1}\right)\end{array}$ \\
\hline $\mathrm{nssCa}^{2+}$ & 31.5 & 26.6 & 22.6 \\
$\mathrm{ssCa}^{2+}$ & 0.8 & 0.4 & 0.3 \\
$\mathrm{nssSO}_{4}^{2-}$ & 12.0 & 8.5 & 6.5 \\
$\mathrm{ssSO}_{4}^{2-}$ & 2.3 & 1.2 & 0.8 \\
$\mathrm{nsSMg}^{2+}$ & 12.2 & 5.1 & 3.1 \\
$\mathrm{ssMg}^{2+}$ & 4.3 & 2.2 & 1.4 \\
$\mathrm{nsSK}^{+}$ & 12.0 & 7.9 & 3.6 \\
$\mathrm{ssK}^{+}$ & 0.4 & 0.2 & 0.1 \\
\hline
\end{tabular}

significantly correlated with $\mathrm{SO}_{4}^{2-}(r=0.83 ; 0.67 ; 0.87), \mathrm{Mg}^{2+}$ $(r=0.82 ; 0.79 ; 0.93)$ and $\mathrm{K}^{+}(0.62 ; 0.56 ; 0.79)$. These correlations indicate that the main terrigenous ions are associated with the formation of eolian particles, including gypsum $\left(\mathrm{CaSO}_{4}\right)$, calcite $\left(\mathrm{CaCO}_{3}\right)$ and dolomite $\left(\mathrm{CaMg}\left(\mathrm{CO}_{3}\right)_{2}\right)$ (Bohn et al., 1985; LoÿePilot et al., 1986; Galy-Lacaux and Modi, 1998) as well as illite $\left[\mathrm{K}(\mathrm{Al}, \mathrm{Mg})_{3} \mathrm{SiA}_{10}(\mathrm{OH})\right]$ (Pitts and Pitts, 1986; Parmar et al., 2001; Nair
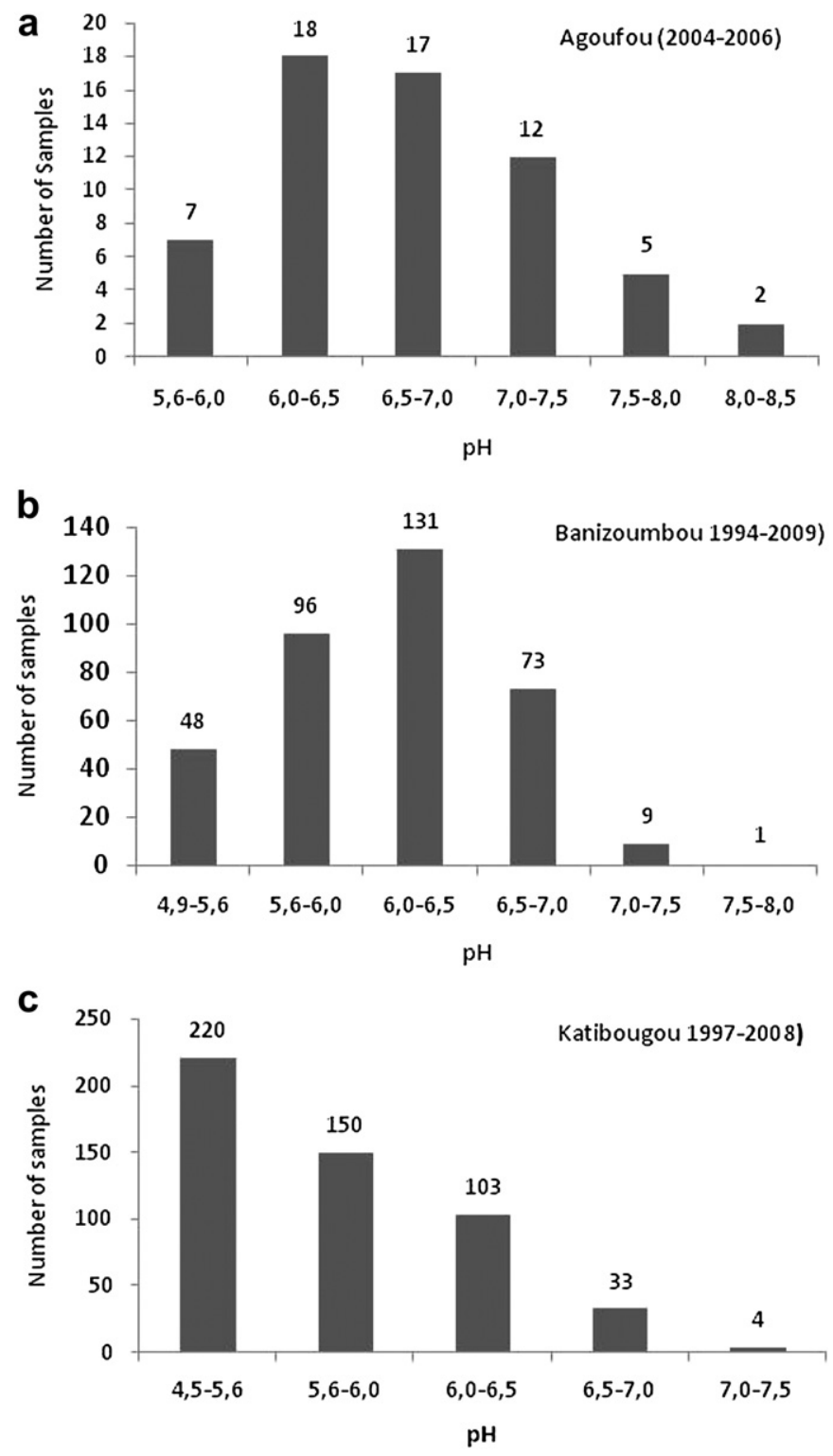

Fig. 3. Frequency distribution of rainfall pH values at the three dry savanna sites. et al., 2006; Kumar et al., 2007; Kulshrestha et al., 2009; Anatolaki and Tsitouridou, 2009). The North African desert areas (Sahel and Sahara) are probably the most important mineral aerosol source globally (Kaufman et al., 2005). Due to the partial dissolution of terrigenous soil dust components, rain in the Sahelian region is loaded with dissolved calcium and carbonates (calcite), which may account for the major fraction of the ionic concentrations of rainwater (Orange et al., 1993; Galy-Lacaux et al., 2009). The origin of potassium ions in rainwater is from washout of mineral dust and from biomass burning aerosols (Yoboué, 1991; Andreae et al., 1988; Crozat et al., 1978).

The study of the VWM concentrations of terrigenous species along the West African transect Agoufou-BanizoumbouKatibougou shows a negative gradient from north to south (Table 2). Non-sea salt calcium concentrations, associated with dust emission, vary from $31.5 \mu$ eq $1^{-1}$ at Agoufou, to $26.6 \mu$ eq $1^{-1}$ at both Banizoumbou and Katibougou. Non-sea salt sulphate, potassium and magnesium concentrations show a similar gradient (Table 4).

The sum of the potential terrigenous species defined by $\mathrm{Ca}^{2+}+\mathrm{Mg}^{2+}+\mathrm{SO}_{4}^{2-}+\mathrm{K}^{+}+$carbonates equals $115.1 \mu \mathrm{eq} \mathrm{l}^{-1}$ and corresponds to $56 \%$ of the total ionic content at Agoufou; to $80.6 \mu \mathrm{eq} \mathrm{l}^{-1}$, or $56 \%$ of the total ionic content at Banizoumbou and to $53.8 \mu \mathrm{eq} \mathrm{I}^{-1}$, or $45 \%$ of the total ionic content at Katibougou. This high terrigenous contribution emphasizes the direct influence of soil dust on rainfall of the Sahelian region. This terrigenous contribution involves highest wet deposition for $\mathrm{Ca}^{2+}: 2.09 \pm 0.56$; $2.75 \pm 0.62$ and $3.65 \pm 0.60 \mathrm{~kg} \mathrm{ha}^{-1} \mathrm{yr}^{-1}$ at Agoufou, Banizoumbou and Katibougou, respectively (Table 2). Two South African IDAF sites, Louis Trichardt and Amersfoort, both in semi-arid savanna (and Amersfoort near industrial sites as well) present wet deposition of $\mathrm{Ca}^{2+}$ of the same order of magnitude: 1.8 and $2.8 \mathrm{~kg} \mathrm{ha}^{-1} \mathrm{yr}^{-1}$ at the two sites respectively (Mphepya et al., 2005).

\subsubsection{Nitrogenous contribution}

$\mathrm{NO}_{\mathrm{x}}$ and $\mathrm{NH}_{3}$ are the main nitrogenous gases emitted in the tropics and are removed in precipitation and aerosol as nitrate $\left(\mathrm{NO}_{3}^{-}\right)$and ammonium $\left(\mathrm{NH}_{4}^{+}\right)$.

$\mathrm{NH}_{4}^{+}$is the main nitrogenous ion found in the rain samples at all three sites. The annual VWM concentration of $\mathrm{NH}_{4}^{+}$is $25.2 \mu \mathrm{eq} \mathrm{l}^{-1}$, $17.9 \mu$ eq $\mathrm{l}^{-1}$ and $19.1 \mu \mathrm{eq} \mathrm{l}^{-1}$ at Agoufou, Banizoumbou and Katibougou respectively (Table 2 ). These values are comparable to those obtained at Kollo, Niger $\left(\mathrm{NH}_{4}^{+}=19.1 \mu \mathrm{eq} \mathrm{l}^{-1}\right.$, Modi et al., 1995) and at Banizoumbou $\left(\mathrm{NH}_{4}^{+}=18.1 \mu \mathrm{eq} \mathrm{l}^{-1}\right.$, Galy-Lacaux et al., 2009). The VWM concentrations calculated at the South African semi-arid savanna sites of Louis Trichardt and Skukuza are 9.0 and $9.7 \mu \mathrm{eq} \mathrm{l}^{-1}$, respectively (Mphepya et al., 2005, 2006).

$\mathrm{NH}_{4}^{+}$content in precipitation results from the incorporation of gaseous ammonia and particles containing $\mathrm{NH}_{4}^{+}$in clouds and rainwater. $\mathrm{NH}_{3}$ originates largely from bacterial decomposition of urea in animal excreta, and from emission by natural or fertilized soils (Schlesinger and Hartley, 1992; Galy-Lacaux and Modi, 1998). Domestic and wild animals also lead to volatilization of ammonia in tropical pastures (Galbally and Gillet, 1988; Schlesinger and Hartley, 1992). Another significant source of ammonia is savanna fires and domestic fuel wood burning (Lobert et al., 1990; Delmas et al., 1995; Brocard et al., 1996). Seinfeld (1986) reported that ammonia generally occurs in the atmosphere as $\left(\mathrm{NH}_{4}\right)_{2} \mathrm{SO}_{4}$, but is also found in the form of $\mathrm{NH}_{4} \mathrm{NO}_{3}$ (Parmar et al., 2000). During the wet season in the Sahelian region the burning of savanna is improbable and the main source of ammonia is likely the hydrolysis of urea from animal urine deposited in grazing areas. High densities of domestic animals are concentrated on the fresh natural pastures which turn green during the rainy season. McCalley and Sparks (2008) measured $\mathrm{NO}$ and $\mathrm{NH}_{3}$ emission from the desertic Mojave soils and indicate that seasonal changes in temperature and 
NOAA HYSPLIT MODEL Backward trajectories ending at 2000 UTC 10 Aug 06 GDSA Meteorological Data

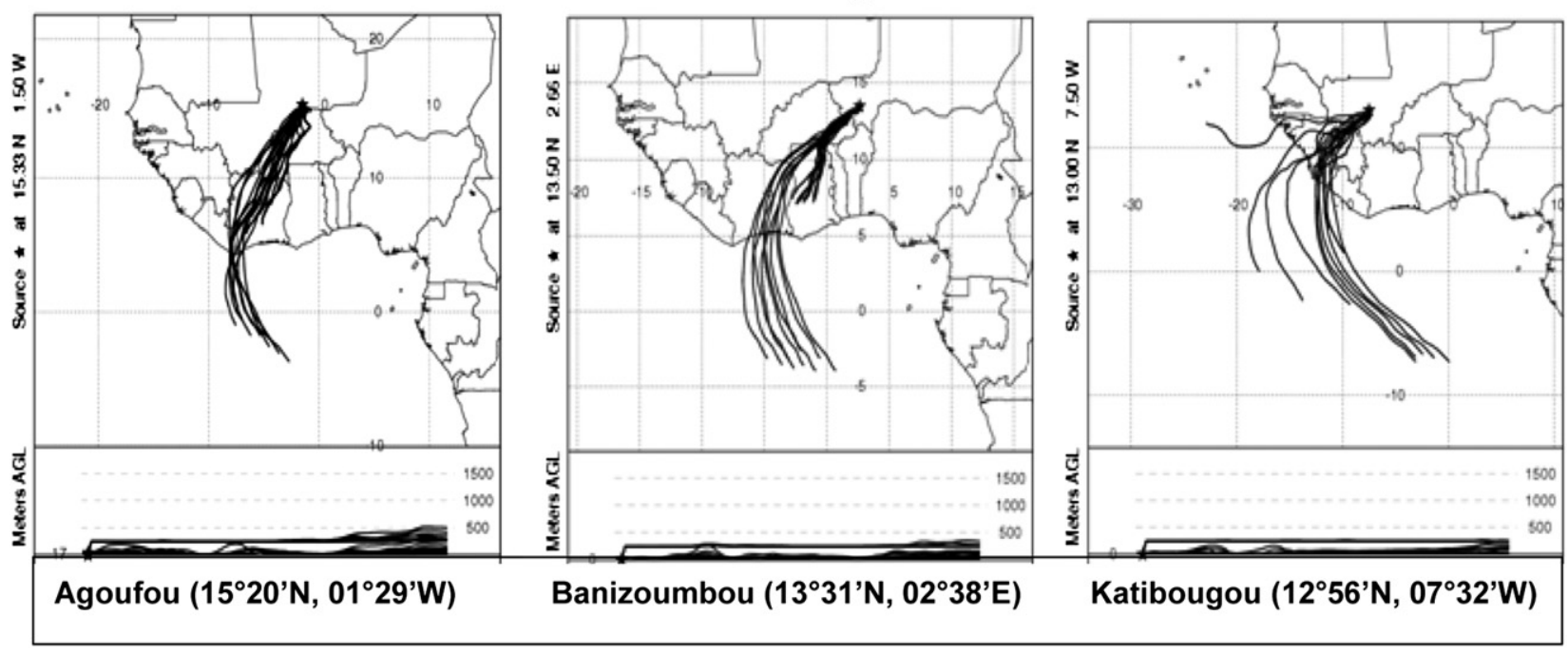

Fig. 4. Back trajectories obtained by means of the NOAA Hysplit Model, giving the direction of the monsoonal air mass during the wet season.

precipitation drive emissions, with maximum deposition fluxes in the wet season ranging $0.9-10 \mathrm{ng} \mathrm{N} \mathrm{m} \mathrm{N}^{-2} \mathrm{~s}^{-1}$ (from 0.3 to $3 \mathrm{~kg} \mathrm{~N} \mathrm{ha} \mathrm{yr}^{-1}$ ). Wet deposition of ammonium of up to $0.88 \mathrm{~kg} \mathrm{~N} \mathrm{ha}^{-1} \mathrm{yr}^{-1}$ at Banizoumbou confirms the intense source of ammonia in this semi-arid savanna region (Galy-Lacaux and Modi, 1998). Atmospheric ammonia fluxes have been estimated in the Sahel and more generally in Africa (Schlecht et al., 1998; Bouwman et al., 2002). In the Sahelian zone, agro-pastoralism appears to be very important, representing 25-30\% of GDP (Gross Production Product). For example, pastoralism contributes $10-15 \%$ of the GDP of both Mali and Niger. Recently, Delon et al. (2010) developed a specific $\mathrm{NH}_{3}$ emission inventory for 23 West African countries. This inventory takes into account the volatilization of $\mathrm{NH}_{3}$ from cattle dung. $\mathrm{NH}_{3}$ volatilization from synthetic fertilizer is negligible in this region (Bouwman et al., 2002). The quantity of nitrogen released by livestock is calculated from Schlecht et al. (1998), in $\mathrm{g} \mathrm{N}$ head $^{-1} \mathrm{day}^{-1}$, for cows, sheep and goats. This estimate is multiplied by the number of animals per $\mathrm{km}^{2}$ in each region of each country concerned, using information from the FAO (Food and Agriculture Organization) and GLiPHA (Global Livestock Production and Health Atlas) database. The mean total nitrogen input from animal manure is estimated to be $23 \mathrm{~kg} \mathrm{~N} \mathrm{ha}^{-1} \mathrm{yr}^{-1}$ at Agoufou, $25 \mathrm{~kg} \mathrm{~N} \mathrm{ha}^{-1} \mathrm{yr}^{-1}$ at Banizoumbou and $11 \mathrm{~kg} \mathrm{~N} \mathrm{ha}^{-1} \mathrm{yr}^{-1}$ at Katibougou, with approximately $30 \%$ of this input released into the atmosphere (Delon et al., 2010). In the Sahel region favorable conditions are encountered for $\mathrm{NH}_{3}$ volatilization, i.e. high temperatures, low soil moisture and bare soils surfaces. Thus, we assume that gaseous $\mathrm{NH}_{3}$ is a significant contributor to the ammonium content of Sahelian precipitation.

In the present study, an intra-annual variation of $\mathrm{NH}_{3}$ volatilization has been added, with higher emissions during the wet season. Indeed, similar to NO production from nitrification, rates of $\mathrm{NH}_{3}$ volatilization should be sensitive to soil conditions that influence $\mathrm{NH}_{4}^{+}$concentrations and turnover in the soil (McCalley and Sparks, 2008). The increase in soil moisture at the beginning of the wet season is correlated to the increase of $\mathrm{NO}$ and $\mathrm{NH}_{3}$ concentrations at the dry savanna sites (Adon et al., 2010).

Furthermore, the excreta quantity is not constant throughout the year, and presents a maximum at the beginning of the dry season at both Agoufou and Banizoumbou (Hiernaux et al., 1998,
2002; Schlecht et al., 1998). Due to a lack of data in Katibougou, we have supposed that the processes are similar to those at the two other sites. The quantity of $\mathrm{N}$ released from animal excreta is therefore maximum in October and November. The combination of these two processes (increased soil moisture at the beginning of the wet season and increased excreta at the beginning of the dry season) gives a monthly evolution of the $\mathrm{NH}_{3}$ volatilization as shown in Fig. 6.

Nitrate contributes the second largest fraction to the nitrogenous content of precipitation at the 3 measurement sites. Concentrations of $14.6 \mu$ eq $l^{-1}, 10.8 \mu \mathrm{eq} \mathrm{l}^{-1}$ and $10.4 \mu \mathrm{eq} \mathrm{l}^{-1}$ were measured at Agoufou, Banizoumbou and Katibougou, respectively. These values are in the same range of those measured at the South African semi-arid savanna sites of Louis Trichardt and Skukuza (8.0 and $8.17 \mu$ eq $1^{-1}$, respectively) (Mphepya, 2005, 2006), the rural Indian site of Iqbalpur (8.6 $\mu \mathrm{eq}^{-1}$ ) (Monika et al., 2000), the wet savanna site of Lamto ( $7.7 \mu \mathrm{eq} \mathrm{l}^{-1}$ ) (Yoboué et al., 2005) as well as at the equatorial forest site of Zoetele $\left(6.9 \mu \mathrm{eq}^{-1}\right)$ (Sigha-Nkamdjou et al., 2003). The concentrations measured at the 3 sites investigated here are lower than those at Amersfoort, South Africa (dry savanna site located near industrial areas; $25.0 \mu \mathrm{eq} \mathrm{l^{-1 }}$ ) (Mphepya et al., 2005).

In the Sahel, microbial processes in tropical savanna soils leads to the production of nitric oxide (NO) (Parsons et al., 1996; Levine et al., 1996; Serca et al., 1994, 1998), the major oxygenated nitrogen compound released from savanna soils. Over the infertile soils of the semi-arid savanna regions of South Africa Parsons et al (1996) measured emission fluxes of $1.1 \mathrm{~kg} \mathrm{~N} \mathrm{ha}^{-1} \mathrm{yr}^{-1}$, the same order of magnitude in size as the deposition fluxes measured in the Sahel. Original measurements of NO emission in the Sahelian savanna at Banizoumbou, where natural emissions are perturbed by grazing activities, indicate rates of $1.9 \pm 0.8 \mathrm{~kg} \mathrm{~N} \mathrm{ha}^{-1} \mathrm{yr}^{-1}$ (Serça et al., 1998). Correlations between $\mathrm{Mg}^{2+}$ and $\mathrm{NO}_{3}^{-}$, and between $\mathrm{Ca}^{2+}$ and $\mathrm{NO}_{3}^{-}$, are around 0.68 at Agoufou, 0.76 at Banizoumbou and 0.83 at Katibougou, indicating potential heterogenous and multiphase chemical processes occurring between alkaline dust and gaseous nitric acid (Dentener et al., 1996; Galy-Lacaux et al., 2001).

Fig. 5(a-c) show the mean monthly variability of $\mathrm{NO}_{3}^{-}$and $\mathrm{NH}_{4}^{+}$ VWM and Fig. 5(d-f) mean monthly wet deposition flux of $\mathrm{NO}_{3}^{-}$ 

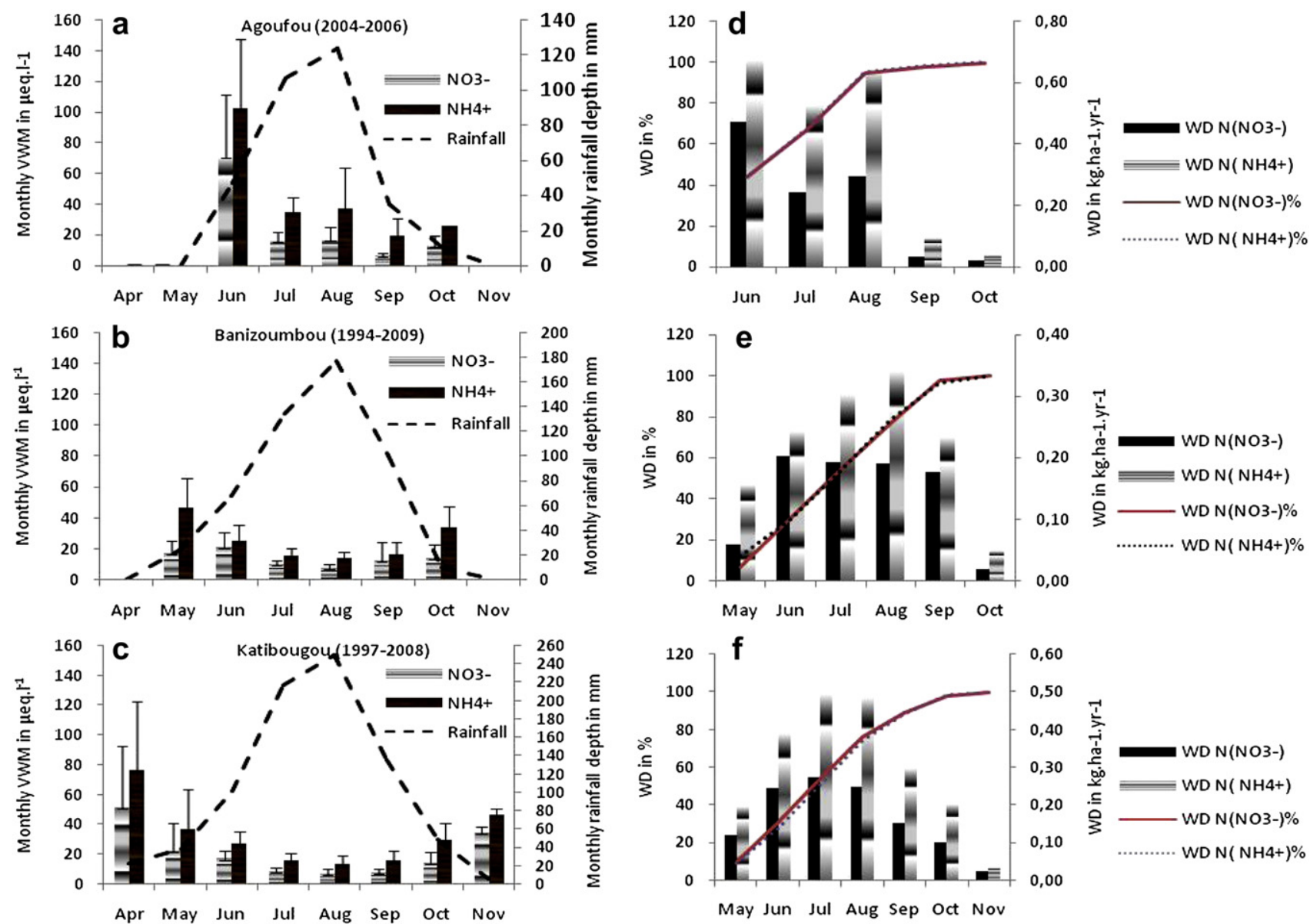

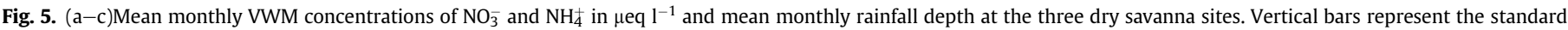

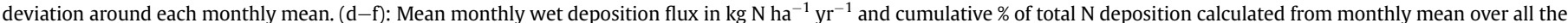
studied periods.

and $\mathrm{NH}_{4}^{+}$as well as the cumulative wet deposition for the study period. Vertical bars indicate the standard deviation while the mean monthly precipitation depth is superimposed upon the monthly VWM concentrations. The range of $\mathrm{NO}_{3}^{-}$and $\mathrm{NH}_{4}^{+}$ concentrations in rain are shown in Fig. $5(\mathrm{a}-\mathrm{c})$. Monthly $\mathrm{NO}_{3}^{-}$and $\mathrm{NH}_{4}^{+}$VWM concentrations begin to increase significantly just after the first rains at the beginning of the wet season (Fig. $5 a-c$ ). Wet deposition fluxes increase throughout the wet season at all three sites. At Agoufou the wet deposition fluxes of ammonia is $1.20 \mathrm{~kg} \mathrm{~N} \mathrm{ha}^{-1} \mathrm{yr}^{-1}$ at the beginning of the wet season and reaches up to $3.10 \mathrm{~kg} \mathrm{~N} \mathrm{ha}^{-1} \mathrm{yr}^{-1}$ by the end of the wet season. Similar patterns are exhibited at Banizoumbou and Katibougou (Fig. 5d-f).

Using the methodology presented by Delon et al. (2010), Fig. $6(\mathrm{a}-\mathrm{c})$ present the monthly mean distribution of $\mathrm{N}$ emission fluxes (i.e. $\mathrm{NO}_{\mathrm{x}}$ from biomass burning (BB), biogenic $\mathrm{NO}$ from soils, $\mathrm{NH}_{3}$ from $\mathrm{BB}$ and $\mathrm{NH}_{3}$ from volatilization) from April to November. Uncertainty bars for each contribution are also shown. The emission flux is dominated firstly by the volatilization of ammonia, and secondly by the biogenic fraction during the wet season at Agoufou and Banizoumbou. At Katibougou, where livestock is less numerous, contributions of biogenic $\mathrm{NO}$ and volatilized $\mathrm{NH}_{3}$ are comparable. The release of ammonia from animal urine and excreta is estimated to be approximately $7.2 \pm 3.7 \mathrm{~kg} \mathrm{~N} \mathrm{ha}^{-1} \mathrm{yr}^{-1}$ at Agoufou, $8.1 \pm 4.2 \mathrm{~kg} \mathrm{~N} \mathrm{ha} \mathrm{yr}^{-1}$ at Banizoumbou and $3.9 \pm 2 \mathrm{~kg} \mathrm{~N} \mathrm{ha}^{-1} \mathrm{yr}^{-1}$ at Katibougou (Delon et al., 2010) (Fig. 6(a-c)). $\mathrm{NH}_{3}$ emission from BB represents only 4\% compared to $\mathrm{NH}_{3}$ volatilization.
Fig. 5(a-f) and $6(a-c)$ can be used to interpret the nitrate and ammonium VWM concentrations measured in precipitation as well as to understand their monthly evolution. At each site (Fig. $5(a-c)$ ) the highest concentration occurs with the first rains, whereas the highest biogenic emission occurs 2-3 months later (Fig. $6(\mathrm{a}-\mathrm{c})$ ) when the wet deposition fluxes of $\mathrm{NH}_{4}^{+}$and $\mathrm{NO}_{3}^{-}$are maximum (Fig. 5(d-f)). Indeed, the first rains are more loaded in $\mathrm{NH}_{4}^{+}$and $\mathrm{NO}_{3}^{-}$due to the scavenging in the lower atmosphere by these first rains, leading to very high concentrations in the precipitation but to relatively low deposition rates. The maximum biogenic emission of NO from soils, occurs in the heart of the wet season, whereas the highest concentrations are found in the beginning of the season (Adon et al., 2010). This is the result of traditional agricultural practices, such as grazing, manure application and decomposition of crop residues, followed by rain on the sandy soils of this area (Jaegle et al., 2004). In fact, the first rains that occur in April-May activate bacterial nitrification, leading to nitrogen consumption and consequently to the release of large pulses of NO (Davidson, 1992; Laville et al., 2005; Ludwig et al., 2001; Williams et al., 1992; Yienger and Levy, 1995). NO is immediately converted into $\mathrm{NO}_{2}$ in the atmosphere through oxidative processes. After the consumption of the excess nitrogen, wet season NO biogenic emissions decrease but remain at relatively high levels compared to the dry season (Serça et al., 1998). Significant correlations are found between $\mathrm{NH}_{4}^{+}$and $\mathrm{NO}_{3}^{-}(r=0.69$ at Agoufou, 0.75 at Banizoumbou and 0.88 at Katibougou), indicating that the above particles originate from similar processes. 

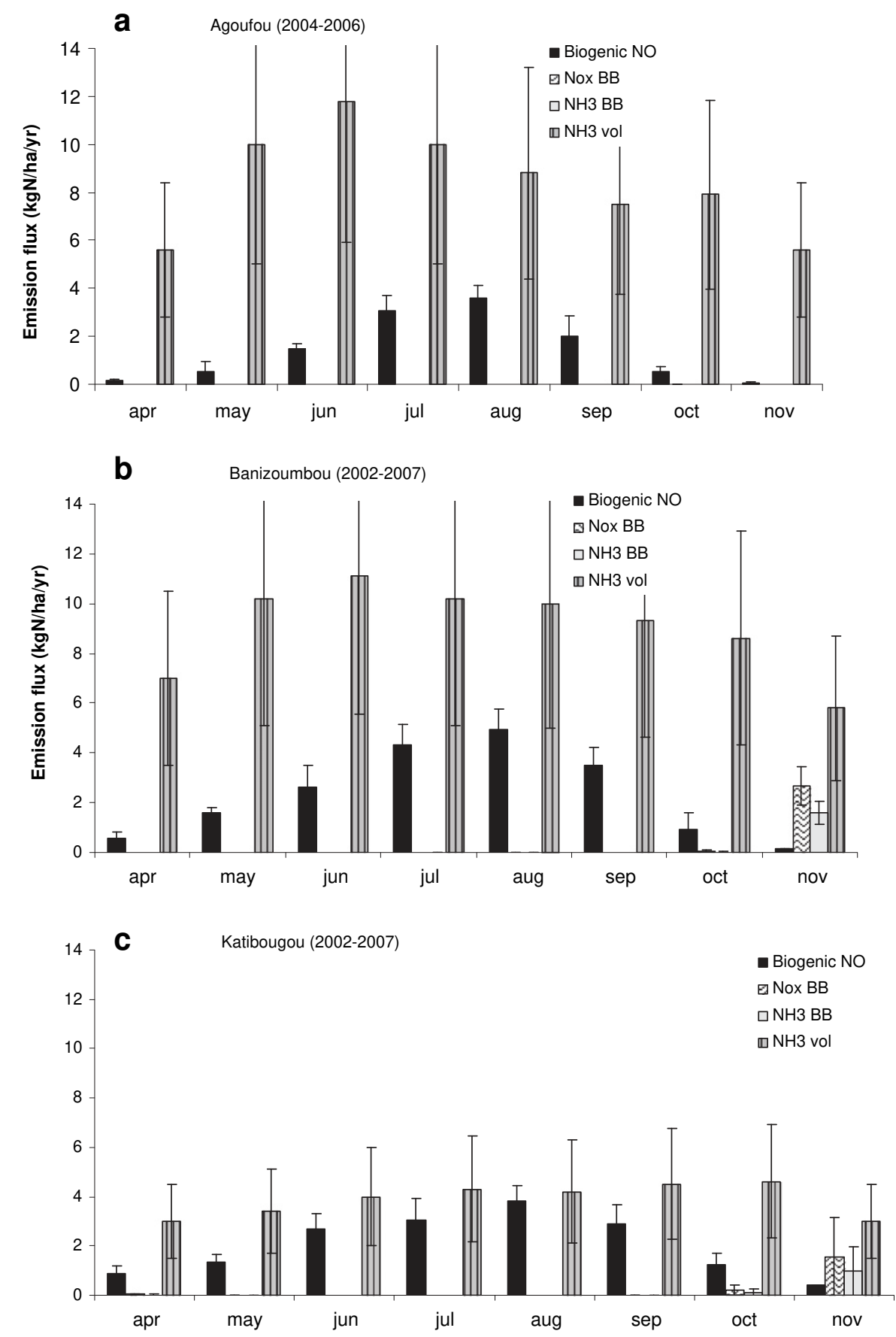

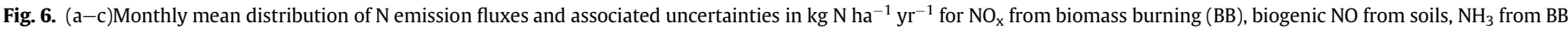
and $\mathrm{NH}_{3}$ from volatilization at the three dry savanna sites.

Indeed, the potential presence of $\mathrm{NH}_{4}, \mathrm{NO}_{3}$ may explain these correlations.

A second maximum occurs at the beginning of the dry season in November at Katibougou. This appears to be associated with biomass burning sources in the Northern Hemisphere during this period (Jaegle et al., 2004), which likely influence the nitrate content of precipitation measured at the end of the monsoon season. At Agoufou and Banizoumbou a second maximum is observed in September. For these sites, we assume that this second peak is likely related to rain events occurring after several dry days, and producing slight pulses of NO from soils. Biomass burning emissions in the region of these sites is very low because of the low quantity of biomass available. In July, when the wet season is well established, $60 \%$ of the total $\mathrm{N}$ wet deposition flux is reached at Agoufou and $50 \%$ at both Banizoumbou and Katibougou. In August, in the heart of the wet season, 90\% of the total flux is reached at Agoufou and $80 \%$ at Banizoumbou and Katibougou.

\subsection{4. $\mathrm{pH}$ and acidity}

Gaseous atmospheric species $\left(\mathrm{NO}_{\mathrm{x}}, \mathrm{SO}_{2}, \mathrm{NH}_{3}\right)$ and water-soluble constituents of the ambient aerosols derived from sea-salts, crustal 
dust and/or anthropogenic or biogenic emissions play a dominant role in the chemical characterization of rainwater on a regional scale. Depending upon their relative contribution, an individual precipitation event can be acidic or alkaline in nature.

Mean $\mathrm{pH}$ measurements for the three Sahelian savanna sites are given in Table 2 while Fig. 3 presents the $\mathrm{pH}$ frequency distribution for the three study sites. The mean $\mathrm{pH}$ is $6.28,5.75$ and 5.54 at Agoufou, Banizoumbou and Katibougou, respectively. The average acidity in the precipitation samples in the three dry savanna sites is weak, with hydrogen ion VWM concentrations equal to $0.5 ; 1.8$ and $3.0 \mu \mathrm{eq} \mathrm{l}^{-1}$ at Agoufou, Banizoumbou and Katibougou, respectively. The $\mathrm{pH}$ values are significantly higher than those reported at the South African semi-arid savanna sites of Amersfoort ( $\mathrm{pH}=4.35$ ) and Louis Trichard ( $\mathrm{pH}=4.91$ ) (Mphepya et al., 2005); but comparable to several other arid and semi-arid rural sites of India (Norman et al., 2001; Pillai et al., 2001; Kulshrestha et al., 2003). Rain acidity at the South African drysavanna sites is higher because of the greater influence by $\mathrm{NO}_{\mathrm{x}}$ and $\mathrm{SO}_{\mathrm{x}}$ industrial emissions from the Highveld region, which are recirculated around the country (Turner et al., 1996; Mphepya et al., 2005, 2006).

Results show that $100 \%$ of the 61 events collected at Agoufou present an alkaline $\mathrm{pH}$ higher than $5.6(\mathrm{pH}=5.6$ being the equilibrium of atmospheric $\mathrm{CO}_{2}$ and cloud water). At Banizoumbou and Katibougou, $87 \%$ of the 358 and $57 \%$ of the 510 rainfall samples, respectively, are also in the alkaline range. The observed alkalinity of rainwater is due to the high loading of particulate matter in the atmosphere common to semi-arid region conditions. Dust is rich in calcium bicarbonate/carbonate representing a major buffering agent for acidity generated by sulphuric, nitric and organic acids (Galy-Lacaux et al., 2001; Khemani et al., 1993; Kulshrestha et al., 2003). We observe a latitudinal geographical gradient of the mean $\mathrm{pH}$, with highest $\mathrm{pH}$ at the most northerly site (Agoufou) and lowest $\mathrm{pH}$ at the southerly site (Katibougou). Our database clearly demonstrates that the $\mathrm{pH}$ gradient is correlated to the calcium gradient measured in rain, which ranges from $32.3 \mu \mathrm{eq} \mathrm{l}^{-1}$ at Agoufou to $27.0 \mu \mathrm{eq} \mathrm{l}^{-1}$ at Banizoumbou and $22.9 \mu \mathrm{eq} \mathrm{l}^{-1}$ at Katibougou.

In spite of the weak acidity found in the precipitation measurements at these three dry savanna sites, the calculated potential contribution of organic acidity (formate, acetate, propionate and oxalate) is 27\% at Agoufou, 39\% at Banizoumbou and 50\% at Katibougou. The potential contribution of mineral acidity, mainly related to the incorporation of $\mathrm{H}_{2} \mathrm{SO}_{4}$ and $\mathrm{HNO}_{3}$, is equal to $73 \%, 61 \%$ and $50 \%$, at the three sites, respectively. These contributions are comparable to measurements made in other African ecosystems. In wet savanna (Lamto) the potential acidity contribution by organic acids is equal to $56 \%$ and the contribution of mineral acids is $44 \%$ (Yoboué et al., 2005). At Amersfoort, an industrial site in a dry savanna ecosystem (South Africa), organic acids contribute only $16 \%$ of the total acidity (Mphepya et al., 2004). The contribution of organic acids (40-60\%) in African forests is equivalent to that of mineral acids (40-60\%). According the modeling work of GalyLacaux et al. (2001), we can assume that almost all the nitric acid available is neutralized by alkaline solid dust particles. Sulfuric acid, a strong acid, is also rapidly captured by alkaline particles. We suppose that the remaining acidity in rain samples is related to organic compounds.

If we define the acidity potential (pA) as the sum of the potential acidic compounds in the form of nitric or sulphuric acids and organic acids, pA is found equal to $39.7 \mu \mathrm{eq} \mathrm{l}^{-1}$ at Agoufou, $33.5 \mu$ eq $\mathrm{l}^{-1}$ at Banizoumbou and $35.1 \mu \mathrm{eq} \mathrm{l}^{-1}$ at Katibougou. The measured acidity (mA) is low and equal to $0.5 \mu$ eq $\mathrm{l}^{-1}, 1.8 \mu$ eq $\mathrm{l}^{-1}$ and $3.0 \mu \mathrm{eq} \mathrm{I}^{-1}$ at Agoufou, Banizoumbou and Katibougou, respectively. Therefore $39.2,31.7$ and $32.1 \mu \mathrm{eq} \mathrm{I}^{-1}$ of $\mathrm{H}^{+}$is
Table 5

Neutralization Factors (NF) of rainwater calculated at the three dry savannas sites.

\begin{tabular}{llllll}
\hline Ecosystem & Station & $\mathrm{pH}$ & $\mathrm{NF}_{\mathrm{Ca}}^{2+}$ & $\mathrm{NF}_{\mathrm{NH}_{4}}^{+}$ & $\mathrm{NF}_{\mathrm{Mg}}^{2+}$ \\
\hline Dry & Agoufou (2004-2006) & 6.28 & 1.12 & 0.87 & 0.57 \\
Savannas & Banizoumbou (2006-2009) & 5.75 & 1.32 & 0.87 & 0.36 \\
& Katibougou (1997-2008) & 5.54 & 1.29 & 1.08 & 0.25 \\
\hline
\end{tabular}

neutralized, at the three dry savanna stations respectively. Evidence for the neutralization of rainwater at the Sahelian sites is provided by good correlations between major anions $\left(\mathrm{NO}_{3}^{-}\right.$and $\left.\mathrm{SO}_{4}^{2-}\right)$ and major terrigenous cations $\left(\mathrm{Ca}^{2+}, \mathrm{NH}_{4}^{+}, \mathrm{Mg}^{2+}\right)$ with coefficients ranging between 0.64 and 0.91 . According to Orange et al. (1993), Dentener et al. (1996), Galy-Lacaux and Modi (1998), Galy-Lacaux et al. (2001), Sigha-Nkamdjou et al. (2003), Yoboué et al. (2005), a large fraction of terrigenous particles in tropical Africa are dominated by $\mathrm{CaCO}_{3}$. This alkaline compound can neutralize gaseous $\mathrm{HNO}_{3}$ to form solid calcium nitrate. The high calcium content can explain $82 \%$ of the neutralized acidity at Agoufou, $85 \%$ at Banizoumbou and $71 \%$ at Katibougou. Other heterogeneous mechanisms suggest that alkaline particles, containing $\mathrm{Mg}^{2+}$ and $\mathrm{K}^{+}$, amongst others, may also contribute to neutralization of acid rain at these three sites. Neutralization of sulfuric and/or nitric acids by bases such as anions (oxides, carbonates or bicarbonates, etc.) associated with base cations such as $\mathrm{Ca}^{2+}, \mathrm{NH}_{4}^{+}, \mathrm{Mg}^{2+}$, etc., can be evaluated by calculating the neutralization factors (NF) using the following equation (Possanzini et al., 1988):

$\mathrm{NF}_{\mathrm{X}}=\mathrm{X} /\left(\mathrm{NO}_{3}^{-}+\mathrm{SO}_{4}^{2-}\right)$

where $\mathrm{X}$ is the chemical component of interest $\left(\mathrm{Ca}^{2+}, \mathrm{NH}_{4}^{+}, \mathrm{Mg}^{2+}\right.$, etc). Table 5 presents the NF calculation for the three measurement sites. NF values for $\mathrm{Ca}^{2+}$ are around 1.1 to 1.3 depending on the site. $\mathrm{NH}_{4}^{+}$and $\mathrm{Mg}^{2+}$ show lower NF values, varying between $0.9-1$ and $0.25-0.57$, respectively. As a result, $\mathrm{Ca}^{2+}$ appears to be the major ion that neutralizes the strong acids, followed by $\mathrm{NH}_{4}^{+}$.

In this study, the annual mean VWM of formate at Agoufou is $4.5 \mu$ eq $1^{-1}, 3.9 \mu$ eq $1^{-1}$ for acetate and $2.2 \mu$ eq $\mathrm{l}^{-1}$ for oxalate. At Banizoumbou formate also dominates with concentrations of $6.6 \mu$ eq $\mathrm{l}^{-1}$ and concentrations of 4.3 and $1.8 \mu \mathrm{eq} \mathrm{l}^{-1}$ for acetate and oxalate, respectively. Katibougou presents higher organic ions concentrations with $10.3 \mu \mathrm{eq} \mathrm{l}^{-1}, 5.2$ and $1.8 \mu \mathrm{eq} \mathrm{l}^{-1}$ for formate, acetate and oxalate, respectively. The organic acidity measured during the monsoon season is significantly higher at Katibougou than at the two other sites. The origin of the high organic acidity at Katibougou can be explained by the presence of a denser vegetation at the site. Indeed, Galy-Lacaux and Modi (1998) as well Guenther et al. (2006) mainly attributed the organic acidity contribution in precipitation composition to the vegetation source of volatile organic carbon. It is hypothesized that the organic acidity measured in the precipitation is related to the vegetation cycle in the Sahel. Fig. 7 presents the values of leaf area index (LAI) from MODIS (Moderate resolution Imaging Spectroradiometer) satellite measurements. Mean LAI is given for three years 2004, 2005 and 2006 at a spatial resolution of $0.1^{\circ} \times 0.1^{\circ}$ around each site, and illustrates the intensity of vegetation coverage and the seasonal cycle of vegetation growth. The vegetation at Katibougou, which is characterized by a Soudano-Sahel climate, is considerably more dense than at the two other sites of Agoufou and Banizoumbou. This vegetation produces biogenic volatile organic compounds (BVOC), as mentioned by Murphy et al. (2010), Reeves et al. (2010), Ferreira et al. (2010). In contrast, north of $12^{\circ} \mathrm{N}$, no BVOC are emitted because of the low vegetation density as seen in Fig. 7. The precipitation is also an important parameter and annual rainfall 


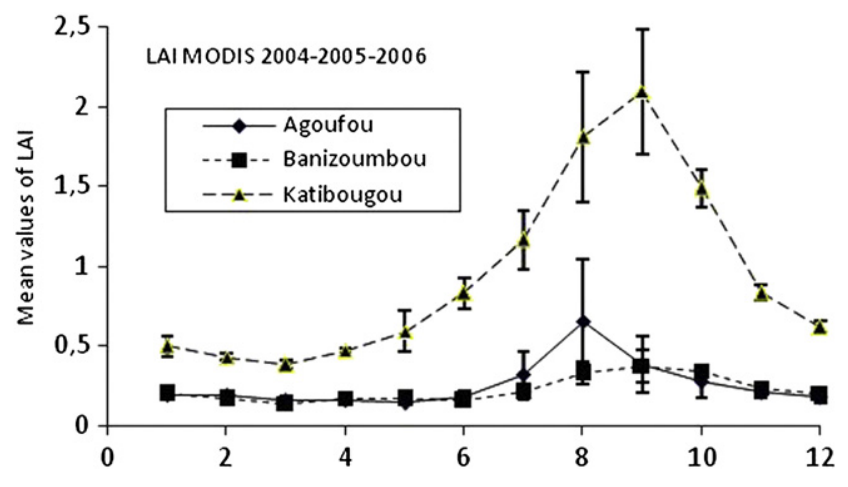

Fig. 7. Values of MODIS Leaf Area Index (LAI) giving the vegetation amplitudes for the years of survey common to the three sites 2004, 2005 and 2006.

measured at Katibougou is higher by a factor of two to three compared to the two other sites. In the Sahel, the seasonal dynamics of the vegetation is strongly determined by rainfall during the monsoon season (Tracol, 2004) (Figs. 8 and 9).

\subsection{Interannual variability of VWM concentrations and wet deposition fluxes}

Annual VWM concentrations and wet deposition fluxes of ionic species are calculated from all data. The results are analyzed to investigate the interannual variability of the major compounds at the three dry savanna sites. The variability can be evaluated as a function of the importance of the main sources and the precipitation intensity at all three sites.

From year to year, the dominant species are the same over the study period. Except for carbonates, the VWM mean concentrations of the four dominant ions in rainfall followed the order: $\mathrm{Ca}^{2+}>\mathrm{NH}_{4}^{+}>\mathrm{Cl}^{-}>\mathrm{NO}_{3}^{-}$at Agoufou and Banizoumbou, and $\mathrm{Ca}^{2+}>\mathrm{NH}_{4}^{+}>\mathrm{NO}_{3}^{-}>\mathrm{HCOO}^{-}$at Katibougou. The two most dominant ions, $\mathrm{Ca}^{2+}$ and $\mathrm{NH}_{4}^{+}$, vary in concentration from 31.3 to $34.1 \mu$ eq $1^{-1}$ and $22.8-26.3 \mu$ eq $1^{-1}$, respectively, at Agoufou; from 20.5 to $36.3 \mu$ eq $\mathrm{l}^{-1}$ and $12.9-26.5 \mu \mathrm{eq} \mathrm{l}^{-1}$ at Banizoumbou and from 16.4 to $27.0 \mu$ eq $\mathrm{l}^{-1}$ and $13.2-23.9$ eq $\mathrm{l}^{-1}$, respectively, at Katibougou. At Agoufou the sum of the species calculated for each

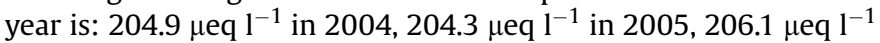
in 2006 (with corresponding mean for the three years is $205.2 \mu \mathrm{eq} \mathrm{l}^{-1}$ ), thus indicating virtually no interannual variability.
This is not the case at the two other sites. Over the 15-year study period at Banizoumbou, the annual sum of species or annual ionic charge varies from a minimum of $111.9 \mu \mathrm{eq} \mathrm{l}^{-1}$ in 1999 to a maximum of $162.2 \mu \mathrm{eq} \mathrm{l}^{-1}$ in 2008 , with a mean of $143.9 \mu \mathrm{eq} \mathrm{l}^{-1}$. At Katibougou, over the 12-year study period, the annual sum ranges from a minimum of $89.7 \mu \mathrm{eq} \mathrm{l}^{-1}$ in 1999 to a maximum of $148.1 \mu$ eq $\mathrm{l}^{-1}$ in 2000 , with a mean of $120.2 \mu$ eq $\mathrm{l}^{-1}$. The total ionic charge in precipitation measured at Banizoumbou and Katibougou shows the same variation in terms of magnitude and direction with a maximum variability of $\pm 25 \%$.

$\mathrm{Na}^{+}$and $\mathrm{Cl}^{-}$ions are identified as major marine compounds, $\mathrm{nssCa}^{2+}, \mathrm{nssMg}^{2+}$ and $\mathrm{nssSO}_{4}^{2-}$ represent the terrigenous contribution, $\mathrm{NO}_{3}^{-}$and $\mathrm{NH}_{4}^{+}$the nitrogenous contribution, formate and acetate the vegetation source. VWM fluctuations for all groups of elements are very low at Agoufou with a variability of $\pm 5 \%$. They are relatively high at Banizoumbou and Katibougou with a similar variability for the terrigenous compounds ( $\pm 25 \%$ ) and $\pm 15 \%$ to $\pm 20 \%$ for the nitrogenous and vegetation groups, respectively. The global tendency of the total deposition for all chemical species follows the same trend as that observed for the chemical concentrations from year to year.

To investigate the wet deposition fluxes, it is important to note that fluxes are directly linked to the rainfall gradient between the three different dry savanna sites. Except for carbonates, the wet deposition flux of ammonium is highest. Recently, results of wet atmospheric nitrogen deposition over Africa have revealed that it is dominated by $\mathrm{NH}_{4}^{+}$, which accounts for about $60 \%$ of the total N flux (IGAC, 2003). For nitrate deposition, fluxes of $0.66 \mathrm{~kg} \mathrm{~N} \mathrm{ha}^{-1} \mathrm{yr}^{-1}, 0.77 \mathrm{~kg} \mathrm{~N} \mathrm{ha}^{-1} \mathrm{yr}^{-1}$ and $1.16 \mathrm{~kg} \mathrm{~N} \mathrm{ha}^{-1} \mathrm{yr}^{-1}$ were measured at Agoufou, Banizoumbou and Katibougou, respectively. These values are within the range of those of the semi-arid savanna site of Louis Trichardt $\left(0.8 \mathrm{~kg} \mathrm{Nha}^{-1} \mathrm{yr}^{-1}\right)$, the wet savanna site of Lamto $\left(1.3 \mathrm{~kg} \mathrm{Nha}^{-1} \mathrm{yr}^{-1}\right)$ and the forest site of Zoetele ( $2.0 \mathrm{~kg} \mathrm{~N} \mathrm{ha}^{-1} \mathrm{yr}^{-1}$ ). Agoufou presents higher wet deposition of the marine compounds $\mathrm{Na}^{+}$, and $\mathrm{Cl}^{-}$ (Table 2). The organic ion wet deposition flux at Katibougou is the highest of all three sites while lower fluxes are found at Agoufou and Banizoumbou. $\mathrm{H}^{+}$deposition fluxes on the three sahelian sites are very low $\left(0.002 \mathrm{~kg} \mathrm{ha}^{-1} \mathrm{yr}^{-1}\right.$ to $\left.0.024 \mathrm{~kg} \mathrm{ha}^{-1} \mathrm{yr}^{-1}\right)$. This gradient of acidity is correlated to the nitrate and the organic ions deposition gradients. Wet deposition fluxes of $\mathrm{H}^{+}$are more important in wet savannas (e.g. at Lamto $0.083 \mathrm{~kg} \mathrm{ha}^{-1} \mathrm{yr}^{-1}$ ) and in equatorial forest (e.g. at Zoetele $0.243 \mathrm{~kg} \mathrm{ha}^{-1} \mathrm{yr}^{-1}$ ). The above results highlight the importance of acidity sources in African wet savanna and forest ecosystems compared to Sahelian dry savannas.

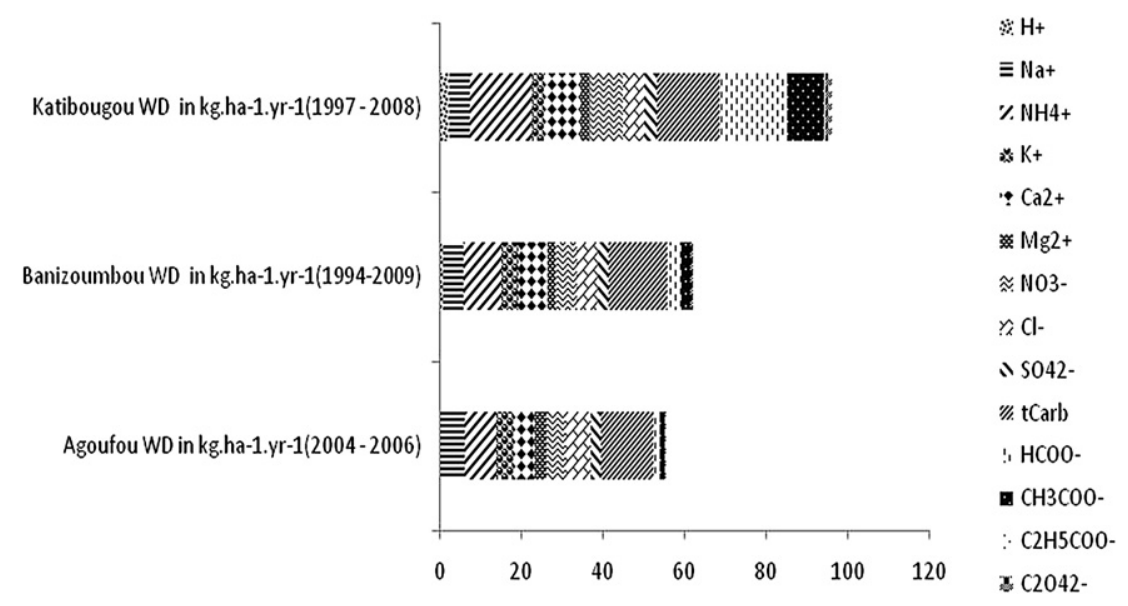

Fig. 8. Mean annual Wet Deposition WD $\left(\mathrm{kg} \mathrm{ha}^{-1} \mathrm{yr}^{-1}\right)$ fluxes over the three African dry savannas calculated from all database. 

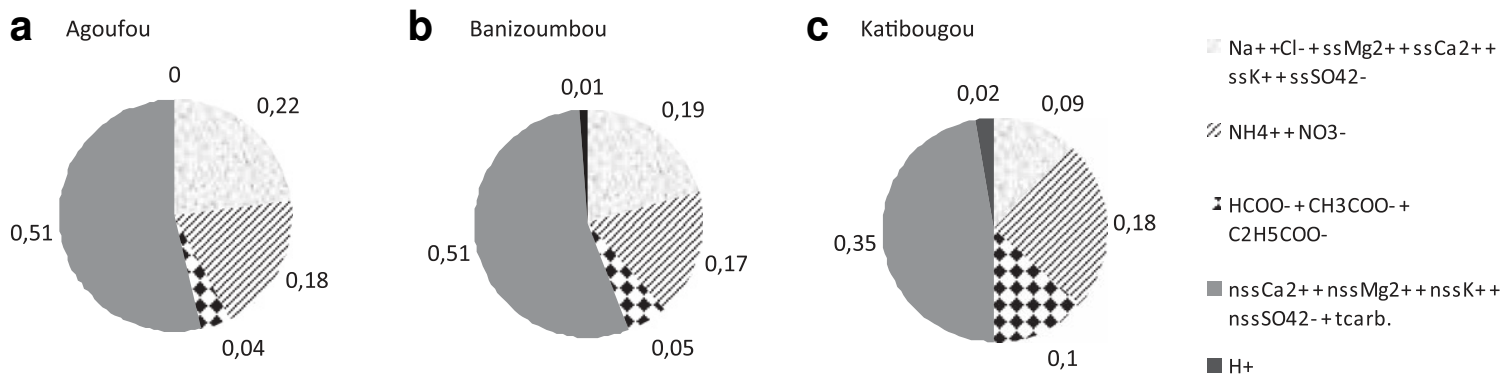

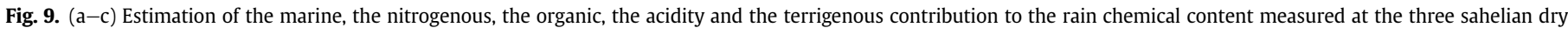
savannas.

\section{Conclusions}

We present the first long-term analysis of the chemical content of precipitation at three Sahelian dry savanna sites: Agoufou (2004-2006), Banizoumbou (1994-2009) and Katibougou (1997-2008). We compare the global precipitation characteristics for the three study sites to other African ecosystems (i.e. wet savanna and forest) and we present a synthesis and a calculation of the different atmospheric source contributions to the precipitation chemical content along the Sahelian transect.

The mean total chemical charge of precipitation for each site is calculated from the volume-weighted mean (VWM) precipitation concentrations (Table 2). Mean total ionic charges present significant negative gradient along the transect Agoufou, Banizoumbou, Katibougou (from 205 to $120 \mu \mathrm{eq} \mathrm{l}^{-1}$ ). In contrast, a clear positive gradient of total wet deposition flux is measured, corresponding to the precipitation gradient.

For the years for which rainfall chemistry measurements are available at all three sites (i.e. 2004-2006), the analysis of the mean total chemical charge indicates similar values and the same negative concentration gradient from Agoufou to Katibougou. The site of Zoetele in the equatorial forest of Cameroon has been studied from 1998 to 2000 and the wet savanna site of Lamto in Ivory Coast from 1996 to 2002 (Sigha-Nkamdjou et al., 2003; Yoboué et al., 2005). The total chemistry charges at these sites are lower compared to the three dry savannas studied in this paper (100.2 and $86.6 \mu$ eq $\mathrm{l}^{-1}$ at Lamto and Zoetele, respectively). The relative global contribution of particles and gases in rainwater is determined using the concept proposed by Yoboué et al. (2005). Results indicate that at Agoufou and Banizoumbou the relative contribution of gases and particles to the chemical content of rain is $80 \%$ and $20 \%$ respectively. For Katibougou, particles and gases contribute $70 \%$ and $30 \%$ of the total, respectively. The particle contribution decreases from 70 to $80 \%$ in the Sahelian dry savannas, to $40 \%$ in wet savannas and $20 \%$ in forests. This is consistent with the high dust emissions from the Sahel, and progressive washout of particles along the transect: dry savannas-wet savanna-equatorial forest.

This study gives a first estimation of the potential contribution of different atmospheric sources identified in the precipitation composition analysis for three sahelian savannas sites. This estimation is done according to groups of sources presented in Section 3.1 and calculated from the mean total charge of each ecosystem for the study period. The main conclusions are:

- terrigenous species are the most abundant compounds, contributing between 46 and $53 \%$ of the total;

- the nitrogenous contribution at the three sites is relatively high and accounts for between 19 and 25\% of the total;

- the marine contribution is lower, contributing between 13 and $23 \%$ of the total;
- finally, organic acidity contibutes between 5 and 14\% of the total at each site.

Terrigenous and marine contributions present a negative gradient whereas there is a positive gradient in nitrogenous and organic contributions along the Sahelian transect defined by AgoufouBanizoumbou-Katibougou. The average rainwater $\mathrm{pH}$ decreases from Agoufou (6.28), to Banizoumbou (5.75) and to Katibougou (5.54). The $\mathrm{pH}$ evolution along this latitudinal gradient is certainly correlated to the negative gradient of the major terrigenous species concentrations along the transect which creates a gradient of potential neutralizing agents for the acidity of precipitation. In the near future, a study of total deposition from the long-term series will allow the analysis of the temporal trends of atmospheric deposition including both wet and dry processes, linked to climate variability and anthropogenic activities in semi-arid African ecosystems.

\section{Acknowledgments}

This work is part of the IDAF (IGAC/DEBITS/AFRICA) project. It has been supported by the "Institut National des Sciences de L'Univers" within the framework of the ORE programme (Observatoire de Recherche en Environnement). Based upon a French initiative, the AMMA project is now supported by an international scientific group including a large number of agencies, especially from France, the United Kingdom, the United States and Africa. It has been the beneficiary of a major financial contribution from the European Community's Sixth Framework Research Programme (FP6), see www.amma-internatio-nal.org <http://-www.amma-international. org $>$. The authors thank A.I. Modi from the University of Niamey, who started the IDAF Banizoumbou site in Niger (in 1994) and the IRD (Institut de Recherche pour le Developpement) in Niamey for logistical support. We thank Drissa Diallo from the University of Bamako who initiated the involvement of the meteorological station of Katibougou at the IPR (Institut Polytechnique Rural) in 1994 with the IRD. We thank Robert Rosset (Laboratoire d'Aérologie, Toulouse) for back trajectory analysis calculations and Pierre Hiernaux (Geoscience Environnement Toulouse) for his personal contribution to the nitrogen section. Finally, we are also grateful to Fiona Tummon for editing the manuscript and all the field technicians of the IDAF network: Alfari Zakou for Banizoumbou in Niger, Hama Maïga for Agoufou in Mali and Kanoute Cheick for Katibougou in Mali.

\section{References}

Adon, M., Galy-Lacaux, C., Yoboué, V., Delon, C., Lacaux, J.P., Castera, P., Gardrat, E., Pienaar, J., Al Ourabi, H., Laouali, D., Diop, B., Sigha-Nkamdjou, L., Akpo, A., Tathy, J., Lavenu, F., Mougin, E., 2010. Long-term measurements of sulphur 
dioxide, nitrogen dioxide, ammonia, nitric acid and ozone in Africa using passive samplers. Atmos. Chem. Phys. Discuss. 10, 4407-4461.

Al-ourabi, H., Lacaux, J.P., 18-25 September, 2002. Dry and wet deposition for nitrogen and sulphur at seven IDAF stations in Tropical Africa. International Global Atmospheric Chemistry (IGAC), Symposium, Crete, Greece.

Anatolaki, C., Tsitouridou, R., 2009. Relationship between acidity and ionic composition of wet precipitation: a two years study at an urban site, Thessaloniki, Greece. Atmos. Res. 92, 100-113.

Andreae, M.O., Browell, E.V., Garstang, M., Gregory, G.L., Harris, R.C., Hill, G.F. Jacob, D.J., Pereia, M.C., Sachse, G.W., Setze, A.S., Silva Dias, P.L., Talbot, R.W., Torres, A.L., Wofsy, S.C., 1988. Biomass burning emission and associated haze layers over Amazonia. J. Geophys. Res. 93, 1509-1527.

Bohn, L., McNeal, B.L., Connor, G.,A., 1985. Soil Chemistry. John Wiley, New York.

Bouwman, A.F., Boumans, L.J., Batjes, N.H., 2002. Estimation of global $\mathrm{NH}_{3}$ volatilization loss from synthetic fertilizers and animal manure applied to arable lands and grasslands. Glob. Biogeochem. Cycles 16 (n2), 1024. doi:10.1029/2000GB001389.

Bravo, H.A., Saavedra, M.I.R., Sanchez, P.A., Torres, R.J., Granada, L.M.M., 2000. Chemical composition of precipitation in a Mexican Maya region. Atmos. Environ. 34, 1197-1204.

Brocard, D., Lacaux, C., Lacaux, J.P., Kouadio, G., Yoboué, V., 1996. Emissions from the combustion of biofuels in western Africa. In: Levine, J.S. (Ed.), Global Biomass Burning. MIT Press, Cambridge.

Chao, C.Y., Wong, K.K., 2002. Residential indoor $\mathrm{PM}_{10}$ and $\mathrm{PM}_{2.5}$ in Hong Kong and the element composition. Atmos. Environ. 36, 265-277.

Crozat, G., Domergue, J.L., Baudet, J., et Bogui, V., 1978. Influence des feux de brousse sur la composition chimique des aerosols atmospheriques en Afrique de 1'Ouest. Atmos. Environ. 12 (9), 1917.

Davidson, E.A., 1992. Pulses of nitric oxide and nitrous oxide flux following wetting of dry soil: an assessment of probable sources and importance relative to annual fluxes. Ecol. Bull. 42, 149-155.

Delmas, R., Lacaux, J.P., Menaut, J.C., Abbadie, L., Leroux, X., Helas, G., Lobert, J., 1995. Nitrogen compound emission from biomass burning in tropical African savanna, FOS/DECAFE experiment. J. Atmos. Chem. 22, 175-194.

Delon, C., Galy-Lacaux, C., Boone, A., Liousse, C., Serça, D., Adon, M., Diop, B. Akpo, A., Lavenu, F., Mougin, E., Timouk, F., 2010. Atmospheric nitrogen budget in Sahelian dry savannas. Atmos. Chem. Phys. 10, 2691-2708.

Dentener, F.J., Carmichael, G.R., Zhang, Y., Lelieveld, Y.J., Crutzen, P.J., 1996. Role of mineral aerosols as a reactive surface in the global troposphere. J. Geophys. Res. 101, 22869-22889.

Dikaiakos, J.G., Tsitouris, C.G., Siskos, P.A., Melissos, D.A., Nastos, P., 1990. Rainwater composition in Athens, Greece. Atmos. Environ. 24B (1०), 171-176.

Draxler, R., Rolph, G., 2003. HYSPLIT Model (Hybrid Single-Particle Lagrangian Integrated Trajectory). NOAA Air Resources Laboraty, Silver Spring, Maryland. Web address: http://www.arl.noaa.gov/ready/hysplit4.html.

Estell, R.E., Fredrickson, E.L., Peters, D.P.C., 2006. Introduction tp special issue Landscape Linkages and cross scale interactions in arid and semiarid ecosystems. J. Arid Environ. 65 (2), 193-195.

Ferreira, J., Reeves, C.E., Murphy, J.G., Garcia-Caruras, L., Parker, D.J., Oram, D.E., 2010. Isoprene emissions modilling for West Africa/MEGAN model evaluation and sensitivity analysis. Atmos. Chem. Phys. 10, 8453-8467.

Galbally, I.E., Gillet, R.W., 1988. Processes regulating nitrogen compounds in the tropical atmosphere. In: Rodhe, H., Herrera, R. (Eds.), Acidification in Tropical Countries, Chapter 3, SCOPE. John Wiley and Sons Ltd.

Galy-Lacaux, C., Modi, A.I., 1998. Precipitation chemistry in the Sahelian Savanna of Niger, Africa. J. Atmos. Chem. 30, 319-343.

Galy-Lacaux, C., Carmichaël, G.R., Song, C.H., Lacaux, J.P., Modi, I., 2001. Heterogenous processes involving nitrogenous compounds and Saharan dust inferred from measurements and model calculations Region. J. Geophys. Res. 106, $12559-12578$.

Galy-Lacaux, C., Laouali, D., Descroix, L., Gobron, N., Liousse, C., 2009. Long-term precipitation chemistry and wet deposition in a remote dry savanna site in Africa (Niger). Atmos. Chem. Phys. 9, 1579-1595.

GAW, 2004. GAW report Manual for the GAW Precipitation Chemistry Programme (GAW Report 160).

Gomes, L., Arrue, J.L., Lopez, M.V., Sterk, G., Richard, D., Gracia, R., Sabre, M., Gaudichet, A., Frangi, J.P., 2003. Wind erosion in a semiarid agricultural area of Spain. Catena 52, 235-256.

Guenther, A., karl, T., Harley, P., Wiedinmyer, P., Palmer, P.I., Geron, C., 2006. Estimates of global terrestrial isoprene emissions using MEGAN (Model of Emissions of Gases and Aerosols from Nature). Atmos. Chem. Phys. 6, 3181-3210. http://www.atmos-chem-phys.net/6/3181/2006.

Hiernaux, P., Fernandez-Rivera, S., Schlecht, E., Turner, M.D., Williams, T.O., 1998. Livestock-mediated nutrient transfers in Sahelian agro-ecosystems. In: Renard, G.A., Neef, A., Becker, K., von Oppen, M. (Eds.), 'Soil Fertility Management in West African Land Use Systems' Niamey, Niger, 4-8.03.97. Margraf Verlag, Weikersheim, Germany, pp. 339-347.

Hiernaux, P., Turner, M.D., 2002. The influence of farmer and pastoralist management practices on desertification processes in the Sahel. In: Reynolds, J.F., Stafford Smith, D.M. (Eds.), Global Desertification: Do Humans Cause Deserts? Dahlem University Press, Berlin, pp. 135-148.

IGAC, 2003. Atmospheric chemistry in a changing word. In: Brasseur,, Guy P., Prinn,, Ronald, Pszenny, G., Alexander, A.P. (Eds.), An Integration and Synthesis of Decade of Tropospheric Chemistry Research. Series: Global Change-The IGBP Series. Hardcover. W. H. Freeman and Company, New York, p. 446, Issue XIV, 300 pp. 131 illus.
Jaegle, L., Martin, R.V., Chance, K., Steinberger, L., Kurosu, T.P., Jacob, D.J., Modi, A.I., Yoboué, V., Sigha-Nkamdjou, L., Galy-Lacaux, C., 2004. Satellite mapping of raininduced nitric oxide emissions from soils. J. Geophys. Res. 109 (D21310) doi:10.1029/2004JD004787.

Janicot, S., Thorncroft, C.D., Ali, A., Asencio, N., Berry, G., Bock, O., Bourles, B., Caniaux, G., Chauvin, F., Deme, A., Kergoat, L., Lafore, J.-P., Lavaysse, C., Lebel, T., Marticorena, B., Mounier, F., Nedelec, P., Redelsperger, J.-L., Ravegnani, F., Re-eves, C.E., Roca, R., de Rosnay, P., Schlager, H., Sultan, B. Tomasini, M., Ulanov-sky, A., ACMAD forecasters team, 2008. Large-scale overview of the summer monsoon over West Africa during the AMMA field experiment in 2006. Ann. Geophys. 26, 2569-2595. doi:10.5194/angeo-262569-2008.

Kaufman, Y.J., Koren, I., Remer, L.A., Tanre, D., Ginoux, P., Fan, S., 2005. Dust transport and deposition observed from the Terra-Moderate resolution Imaging Spectroradiometer (MODIS) spacecraft over the Atlantic Ocean dust transport and deposition observed from the Terra-Moderate resolution Imaging Spectroradiometer (MODIS) space. J. Geophys. Res. 110 (D24202). doi:10.1029/ 2003JD004436.

Keene, W.C., Pszenny, A.A., Galloway, J.N., Hartley, M.E., 1986. Sea-salt corrections and interpretation of constituent ratios in marine precipitation, 1986 corrections and interpretation of constituent ratios in marine precipitation. J. Geophys. Res. 91, 6647-6658.

Khemani, L.T., Momin, G.A., Naik, M.S., Prakassa, R., Kumar, R., Ramana, M., 1993 Impact of alkaline particulates on pH of rainwater in India. Water Air Soil Poll. 24, 365-376.

Kulshrestha, U.C., Kulshrestha, Monika J., Sekar, R., Sastry, G.S.R., Vairamani, M., 2003. Chemical characteristics of rainwater at an urban site of south-central India. Atmos. Environ. 30, 4149-4154.

Kulshrestha, U.C., Granat, L., Engardt, M., Rodhe, H., 2005. Review of precipitation monitoring studies in India-a search for region patterns. Atmos. Environ. 39, 7403-7419.

Kulshrestha, A., Satsangi, P.G., Masih, J., Taneja, A., 2009. Metal concentration of $\mathrm{PM}_{2.5}$ and $\mathrm{PM}_{10}$ particles and seasonal variations in urban and rural environment of Agra, India. Sci. Tot. Env 407, 6196-6204.

Kumar, R., Srivastav, S.S., Kumari, K.M., 2007. Characteristics of aerosols over suburban and urban site of semiarid region in India: seasonal and spatial variations. Aerosol Air Qual. Res. 7, 531-549.

Lacaux, J.P., Cahier, H., Delmas, R., 1993. Biomass burning in Africa: an overview of its impact on atmospheric chemistry. In: Cruzen, P.J. (Ed.), Fire in the Environnement: The Ecological Atmospheric and Climatic Importance of Vegetation Fires. John Wiley and Sons, New York.

Lacaux, J. P., Tathy, J.P., and Sigha L., 2003. Acid wet deposition in the tropics: two case studies using DEBITS measurements, IGACtivities Newsletter of the International Global Atmospheric Chemistry Project, DEBITS Special Issue $\mathrm{N}^{\circ} 27$.

Laville, P., Hénault, C., Gabrielle, B., Serça, D., 2005. Measurement and modelling of NO fluxes over maize andwheat crops during their growing seasons: effect of crop management. Nutr. Cycl. Agroecosyst. 72, 159-171.

Lebel, T., Parker, D.J., Flamant, C., Bourles, B., Marticorena, M., Mougin, E., Peugeot, C., Diedhiou, A., Haywood, J.M., Ngamini, J.B., et al., 2010. The AMMA field campaigns: multiscale and multidisciplinary observations in the West African region. Q. J. R. Meteorol. Soc. 136 (S1), 8-33. doi:10.1002/qj.486.

Levine, J.S., Winstead, L.E., Parsons, D.A.B., Scholes, M.C., Scholes, R.J., Cofers III, W.R., Cahoon Jr., D.R., Sebacher, D.I., 1996. Biogenic soil emissions of nitric oxide (NO) and nitrous oxide $\left(\mathrm{N}_{2} \mathrm{O}\right)$ from savanna in South Africa. J. Geophys. Res. 101 23089-23697.

Lobert, J.M., Scharffe, D.H., Hao, W.M., Crutzen, P.J., 1990. Importance of biomass burning in the atmospheric budgets of nitrogen containing gases. Nature 346 , $552-554$

Löye-Pilot, M.D., Martin, J.M., Morelli, J., 1986. Influence of Saharan dust on the rain acidity and atmospheric input to the Mediterranean. Nature 321, 427-428.

Ludwig, J., Meixner, F.X., Vogel, B., Forstner, J., 2001. Soil-air exchange of nitric oxide: an overview of processes, environmental factors and modelling studies. Biogeochemistry 52, 225-257.

Mayaux, P., Bartholomé, E., Fritz, S., Belward, 2004. A new land-cover map of Africa for the year 2000. J. Biogeography 31, 861-877.

McCalley, C.K., Sparks, J.P., 2008. Controls over nitric oxide and ammonia emissions from Mojave Desert soils. Oecologial 156, 871-881.

Minoura, H., Iwasaka, Y., 1996. Rapid change in nitrate and sulphate concentrations observed in early stage of precipitation and their deposition processes. J. Atmos. Chem. 24, 39-55.

Modi, A.I., Lacaux, J.P., Labroue, L., Baudet, J.G., 1995. R.: Chimie des aérosols et des pluies dans la savane semi-aride du Niger pendant la saison humide 1989. Sécheresse 6, 331-335.

Mohr, Karen, I., Molinari, John, Thorncroft, Chris D., 2009. The interannual Stability of cumulative frequency distributions for convective system size and intensity. J. Clim. 22, 5218-5231. doi:http://dx.doi.org/10.1175/2009JCLI2940.1.

Monika, Jain, Kulshrestha, U.C., Sarkar, A.K., Parashar, D.C., 2000. Influence of crusta aerosols on wet deposition at urban and rural sites in India. Atmos. Environ. 34, 5129-5137.

Mougin, E., Hiernaux, P., Kergoat, L., Grippa, M., De Rosnay, P., Timouk, F., Le Dantec, V., Demarez, V., Arjounin, M., Lavenu, F., Soumaguel, N., Ceschia, E., Mougenot, B. Baup, F., Frappart, F., Frison, P.L., Gardelle, J., Gruhier, C., Jarlan, L., Mangiarotti, S., Sanou, B., Tracol, Y., Guichard, F., Trichon, V., Diarra, L., Soumaré, A., Koité, M., Dembélé, F., Lloyd, C., Hanan, N.P., Damesin, C., Delon, C., Serça, D., Galy-Lacaux, C. 
Seghiéri, J., Becerra, S., Dia, H., Gangneron, F., Mazzega, P., 2009. The AMMACATCH Gourma observatory site in Mali: Relating climatic variations to changes in vegetation, surface hydrology, fluxes and natural resources. J. Hydrology. doi:10.1016/j.Jhydrol.2009.06.045 AMMA-CATCH Special issue.

Mphepya, J.N., Pienaar, J.J., Galy-Lacaux, C., Held, G., Turner, C.R., 2004. Precipitation chemistry in semi-arid areas of Southern Africa: a case study of a rural and an industrial site. J. Atmos. Chem. 47, 1-24.

Mphepya, J.N., Galy-Lacaux, C., Lacaux, J.P., Held, G., Pienaar, J.J., 2005. Precipitation chemistry and wet deposition in Kruger National Park, south Africa. J. Atmos. 13-28.

Mphepya, J.N., Galy-Lacaux, C., Lacaux, J.P., Held, G., Pienaar, J.J., 2006. Precipitation chemistry and wet deposition in Kruger National Park, south Africa. J. Atmos. $53,169-183$.

Murphy, J.G., Oram, D.E., Reeves, C.E., 2010. Measurements of volatile organic compounds over West Africa. Atmos. Chem. Phys. 10, 5281-5294.

Nair, P.R., George, S.K., Sunilkumar, S.V., Parameswaran, K. Jocab, S., Abraham, A 2006. Chemical composition of aerosols over peninsular India during winter. Atmos.Environ. 40, 6477-6493.

Norman, M., Das, S.N., Pillai, A.G., Granat, L., Rodhe, H., 2001. Influence of air mass trajectories on the chemical composition of precipitation in India. Atmos. Environ. 35, 4223-4235

Orange, D., Gac, J.Y., Diallo, M.I., Diallo M.I., Geochemical assessment of atmospheric deposition including Harmattan dust in continental West Africa. IAHS Publ. Proceedings of Yokohama Symposium, 215, 303-312, 1993.

Parmar, R.S., Satsangi, G.S., Kumari, M., Lakhani, A., Srivastav, S.S., Prakash, S., 2001 study of size distribution of atmospheric aerosol at Agra. Atmos. Environ. 35, 693-702.

Parmar, R.S., Satsangi, G.S., Lakhani, A., Srivastava, S.S., Prakash, S., Rastogi, R.K., Ramkumar, K.L., Venugopal, V., Manohar, S.B., 2000. Diurnal and Season Behaviour of Atmospheric Ammonia and Nitric Acid in a Suburban Site. In: Proceedings of the 10th National Symposium on Environment-Pollution in Urban Environment, 66-70 pp.

Parsons, D.A.B., Scholes, M.C., Scholes, R.J., Levine, J.S., 1996. Biogenic NO emissions from savanna soils as a function of fire regime, soil type, soil nitrogen and water status. J. Geophys. Res. 101, 23683-23688.

Pitts, B.J., Pitts Jr., J.N., 1986. Atmospheric Chemistry, Fundamentals and Experimental Techniques. Wiley, New York.

Pillai, A.G., Naik, M.S., Momin, G.A., Rao, P.D., Safai, P.D., Ali, K., Rodhe, H., Granat, L., 2001. Studies of wet deposition and dustfall at Pune, India. Water Air Soil Pollut. $130,475-480$.

Placet, M., Streets, D.B., 1987. First interim assessment, National Acid Precipitation Assessment Programme,722 Jackson place, NW, Washington DC.

Possanzini, M., Buttini, P., Di Palo, V., 1988. Characterization of a rural area in terms of dry and wet deposition. Sci. Total Environ. 74, 111.

Quiterio, S.L., Sousa, D.S., Célia, R., Arbilla, G., 2004. Escaleira: metals in airborne particulate matter in the industrial district of SantaCruz, Rio de Janeiro, in an annual period. Atmos. Environ. 38, 321-331.

Reeves, C.E., Formenti, P., Afif, C., Ancellet, G., Attie, J.L., Bechara, J., Borbon, A. Cairo, F., Coe, H., Crumeyrolle, S., et al., 2010. Chemical and aeroso characterisation of the troposphere over West Africa during the monsoon period as part of AMMA. Atmos.Chem. Phys. 10, 7575-7601.

Ro, C.U., Tang, A.J.S., Chan, W.H., Kirk, R.W., Reid, N.W., Lusis, M.A., 1988. Wet and dry deposition of sulphur and nitrogen compounds in Ontario. Atmos. Environ. 22 (12), 2763-2772.

Saxena, A., Kulshrestha, U.C., Kumar, N., Kumari, K.M., Srivastava, S.S., 1996. Characterization of precipitation at Agra. Atmos. Environ. 30 (20), 3405-3412.

Schlecht, E., Fernndez-Rivera, S., Hiernaux, P., 1998. Timing, size and N-concentration of faecal and urinary excretions in cattle, sheep and goats-can they be used for better manuring of cropland? In: Renard, G., Neef, A., Becker, K., von Oppen, M. (Eds.), Soil Fertility Management in West African Land Use Systems. Margraf Verlag, Weikersheim, Germany, pp. 361-368.

Schlesinger, W.H., Hartley, A.E., 1992. A global budget for atmospheric $\mathrm{NH}_{3}$. Biogeochemistry 15, 191-211.

Seinfeld, J.H., 1986. Atmospheric Chemistry and Physics of Air Pollution. Wiley, New York.

Serca, D., Delmas, R., Jambert, C., Labroue, L., 1994. Emissions of nitrogen oxides from equatorial rainforest in central Africa. Origin and regulation of NO emission from soils. Tellus 46B, 243-254.

Serça, D., Delmas, R., Le Roux, X., Parsons, D.A.B., Scholes, M.C., Abbadie, L., 1998 co-authors. Comparison of nitrogen monoxide emissions from several African tropical ecosystems and influence of season and fire. Glob. Biogeochem. Cy. 12, 637-651.

Sigha-Nkamdjou, L., Galy-Lacaux, C., Pont, V., Richard, S., Sighoumnou, D., Lacaux, J.P., 2003. Rainwater chemistry and wet deposition over the equatorial Forested ecosystem of Zoétélé (Cameroon). J. Atmos. Chem. 46, 173-198.

Tracol, Y., 2004. Etude des variations interannnuelles de la production herbacée des pâturages sahéliens: Exemple du Gourma malien, Thèse de doctorat, Université Paul Sabatier, Toulouse, France.

Turner, C.R., Wells, R.B., Olbrich, K.A., 1996. Deposition chemistry in south Africa. In: Held, G., Gore, B.J., Surridge, A.D., Tosen, G.R., Turner, C.R., Walmsley, R.D. (Eds.), Air Pollution and Its Impacts on the South African Highveld. Environ. Sci. Assoc., Cleveland, USA, pp. 80-85.

Voldner, E.C., Barrie, L.A., Sirois, A., 1986. A review of dry deposition of sulphur and nitrogen with emphasis on long range transport modeling in North America. Atmos. Environ. 20, 2101-2123.

Williams, E.J., Guenther, A., Fehsenfeld, F.C., 1992. An inventory of nitric oxide emissions from soils in the United States. J. Geophys.Res 97, 7511-7519.

WMO, November 2004. Manual for the GAW Precipitation Chemistry Programme Guidelines, Data Quality Objectives and Standard Operating Procedures (WMO TD No. 1251), 186 pp.

Yienger, J.J., Levy II, H., 1995. Empirical model of global soil biogenic NOx emissions. J. Geophys. Res. 100, 11447-11464

Yoboué,V., 1991. Caractéristiques physiques et chimiques des aérosols et des pluies collectés dans la savane humide de Côte d'Ivoire, PhD. No 914, Uni. Paul Sabatier, Toulouse, France.

Yoboué, V., Galy-Lacaux, C., Lacaux, J.P., Silué, S., 2005. Rainwater chemistry and wet deposition over the wet savanna ecosystem of Lamto (Côte d'Ivoire). J. Atmos. Chem. 52, 117-141. 